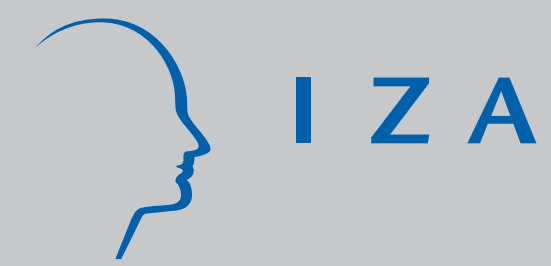

IZA DP No. 2435

Residential Mobility and Housing Adjustment of Older Households in Europe

Konstantinos Tatsiramos

November 2006 


\title{
Residential Mobility and Housing Adjustment of Older Households in Europe
}

\author{
Konstantinos Tatsiramos \\ IZA Bonn
}

\section{Discussion Paper No. 2435 \\ November 2006}

\author{
IZA \\ P.O. Box 7240 \\ 53072 Bonn \\ Germany
}

Phone: +49-228-3894-0

Fax: +49-228-3894-180

E-mail: iza@iza.org

\begin{abstract}
Any opinions expressed here are those of the author(s) and not those of the institute. Research disseminated by IZA may include views on policy, but the institute itself takes no institutional policy positions.

The Institute for the Study of Labor (IZA) in Bonn is a local and virtual international research center and a place of communication between science, politics and business. IZA is an independent nonprofit company supported by Deutsche Post World Net. The center is associated with the University of Bonn and offers a stimulating research environment through its research networks, research support, and visitors and doctoral programs. IZA engages in (i) original and internationally competitive research in all fields of labor economics, (ii) development of policy concepts, and (iii) dissemination of research results and concepts to the interested public.
\end{abstract}

IZA Discussion Papers often represent preliminary work and are circulated to encourage discussion. Citation of such a paper should account for its provisional character. A revised version may be available directly from the author. 


\section{ABSTRACT \\ Residential Mobility and Housing Adjustment of Older Households in Europe}

This paper investigates the determinants of residential mobility of older households (above 50 years old) and the adjustment of housing for those who move employing individual data from the European Community Household Panel. Although homeowners are less likely to move compared to renters, an increase in mobility rates is observed for older age homeowners. Moreover, having an outstanding home loan, retirement, the death of a spouse, and excessive housing costs, are significantly associated with a move in central and northern European countries, but not in the south. Analyzing the transitions from the current tenure choice after a move takes place, based on a competing risk hazard model, an increasing transition out of the current residence for old-age homeowners is found, indicating some dissaving later in life. The direction of the transitions is mostly from ownership to renting. However, especially in countries in central and northern Europe, transitions from ownership to ownership are also observed, which are associated with a reduction in the home size.

JEL Classification: J14, R21, R23

Keywords: residential mobility, ageing, housing tenure choice, competing risk hazard

Corresponding author:

Konstantinos Tatsiramos

IZA

P.O. Box 7240

D-53072 Bonn

Germany

E-mail: tatsiramos@iza.org

\footnotetext{
* I wish to thank Michael Haliassos, Andrea Ichino, Karl Schlag and Jan van Ours for valuable suggestions and comments. I am also grateful to Ana Rute Cardoso, Pierre-Carl Michaud, Albert Saiz, Frederic Vermuelen, and participants at the IZA Workshop on Ageing and the 5th AGE Meeting at Tilburg University for their comments. The financial support provided through the European Community's Human Potential Programme under contract HPRN-CT-2002-00235 [AGE], and the hospitality of people at Tilburg is greatly acknowledged. Any remaining errors are only mine.
} 


\section{Introduction}

One of the issues frequently discussed in the recent years is the demographic change that takes place in developed countries. The proportion of old age households is expected to increase due to higher life expectancy and lower fertility rates, which will have considerable economic and social effects. The most common concern is related to social security and the pressure that the increased fraction of the population that reaches retirement will put on the system. The increase of the average age in the population combined with the need for social security reforms raises issues regarding the well-being of the older population, which are also related to their consumption and saving behavior. According to the Life-Cycle Hypothesis (LCH), accumulated wealth by individuals while they are young is expected to decline at a certain age so that they can smooth consumption at older age. Inadequate savings when individuals are young may lead to poverty in later years, as well as, the inability to adjust current to desired consumption as they become older.

This paper focuses on the decisions of older households which are related to their housing situation. Housing is one of the most important components of wealth for a large part of the households which serves not only as an asset but also provides consumption services. Therefore, appropriate housing in terms of financial and physical needs determines to a great extent the well-being of the older population. Changes in the family structure, financial situation, and physical needs, create a gap between the desired and the current housing consumption. While housing adjustment might require a move, mobility constraints or individual preferences might prevent older households from moving, which means, that they will be occupying inappropriate housing. This raises the question whether government intervention is required, and if so, whether policies should be targeted towards reducing the mobility constraints, or towards programs that permit older households to remain at their homes but at the same time allow them to adjust their housing consumption. ${ }^{2}$

The main contribution of this paper is that it offers a comparison across European countries on the determinants of mobility and the adjustment of housing later in life based on housing tenure transitions. This is achieved by employing individual panel data from the eight waves of the European Community Household Panel covering the years from 1994 to $2001 .^{3}$

\footnotetext{
${ }^{2}$ Programs, such as reverse mortgages, allow households to borrow money against the value of their owned homes so that they can adjust their housing consumption without being forced to move (Mitchell and Piggott, 2004).

${ }^{3}$ The ECHP is a survey based on a standardized questionnaire with annual interviewing of a representative panel of households and individuals in each country, covering a wide range of topics including demographics, employment characteristics, education, housing etc. In the first wave, a sample of some 60,500 households -
} 
Evidence is provided for Austria, Belgium, Denmark, Finland, France, Germany, Greece, Ireland, Italy, Netherlands, Portugal, Spain, and the United Kingdom (U.K.). These countries vary in terms of the distribution across types of tenure, which is mainly the outcome of different housing policies implemented over the years. These policies have favored owneroccupation in countries such as Greece, Italy, Spain, and the U.K., while other countries, such as the Netherlands and Germany, have adopted policies which created a balance between the social and the private rental market, and owner occupation (Balchin, 1996).

The analysis is based on all households, single or couples, with members above 50 years old. Residential mobility is less common in the southern than in the central and northern Europe. Although homeowners are less likely to move compared to renters, an increase in mobility rates is observed for older age homeowners. Moreover, having an outstanding home loan, retirement, the death of a spouse, and excessive housing costs, are significantly associated with a move in the central and northern European countries, but not in the south.

The positive effect of age on mobility, for homeowners, is in line with the prediction of the LCH according to which there should be a decline of the desired housing consumption with age, which results in a move (Hurd, 1990). Analyzing the transitions from the current tenure choice after a move takes place, based on a competing risk hazard model, an increasing transition out of the current residence for older homeowners is found, indicating some dissaving later in life. The direction of the transitions is mostly from ownership to renting. However, especially in countries in the central and northern Europe, transitions are also observed from ownership to ownership, which are associated with a reduction in the home size.

Previous research has mainly analyzed U.S. data finding little evidence of decumulation of housing wealth. In particular, Venti and Wise (2002; 2004) using a variety of microeconomic datasets (the Health and Retirement Study, the Asset and Health Dynamics Among the Oldest Old, and the Survey of Income and Program Participation) find no decline in homeownership before age 75. Reductions in home equity are usually associated with precipitating shocks (e.g. spouse's death, health shocks). Merill (1984), using the Retirement History Survey, shows that the transitions from renter to owner are more likely for the retired households than from owner to renter. Feinstein and McFadden (1989), using the Panel Survey of Income and Dynamics (PSID) also concluded that the elderly do not move unless situation, the standardized methodology and procedures yielding comparable information across countries and the longitudinal design in which information on the same set of households and persons is gathered. 
there are changes in the household structure. Sheiner and Weil (1992), provide evidence that homeownership rates decline with age emphasizing the importance of the widowhood and health shocks.

International evidence and in particular for Europe is rare. Ermisch and Jenkins (1999), study the determinants of residential mobility and the adjustment of housing consumption later in life for the U.K. using the British Household Panel Survey (BHPS). They find that the residential mobility of the elderly is rare, with some downsizing for those households who do move. Börsch-Supan (1994), provides a detailed description of the housing situation for Germany based on the German Socio-Economic Panel finding that the German households do not decrease their housing consumption as they age and that the mobility rates are low. Recently, Chiuri and Japelli (2006), explore the pattern of elderly homeownership in 17 OECD countries finding that ownership rates decline considerably after age 60 in most countries, but most of the decline depends on cohort effects. Adjusting for this, ownership rates fall after age 70 by about half a percentage point per year.

The remaining of the paper is organized as follows. In Section 2, the distribution of housing tenure is described across countries and across age groups, while Section 3 analyzes the determinants of residential mobility. Section 4 focuses on housing adjustment through housing tenure transitions, and Section 5 concludes.

\section{Housing Tenure}

Figure 1 shows homeownership rates by country for 1994 and 2001 for households above 50 years old. ${ }^{4}$ Owner-occupation is highest in Greece, Italy, Spain, and Finland, exceeding 80 per cent, followed by Denmark, France, Portugal and the U.K., around 70 per cent, while ownership rates are much lower, around 50 per cent in Germany and the Netherlands. The distribution of housing tenure for older households follows the pattern observed for the total population, with the Netherlands and Germany having the lowest proportion of tenure in owner-occupation. Ownership rates increase towards the end of the 90 's, which for most countries is related to the housing market boom of that period associated with the very low interest rates after the introduction of the Euro currency (ECB, 2003).

The differences in the homeownership rates across countries are influenced by

\footnotetext{
${ }^{4}$ In what follows, the sample consists of all households (couples or singles), above 50 years old at the first observed wave, which remain in the sample for at least two consecutive years. For couples, this ensures that in case one of the spouses dies the individual who remains in the sample is above 50 years old.
} 
government intervention and market forces which affect both the demand and the supply of housing. The most common forms of government intervention include housing allowances, mortgage interest tax relief, and exemptions from capital gains tax. However, the extent and the direction of government intervention is related to the sociopolitical system in operation in each country (Balchin, 1996). Depending on the political ideology, there are countries such as the Netherlands, Germany, and to a lesser extent France, in which social policy intervention creates a balance between private and social rented housing. Social rented housing competes with the private rental sector dampening rents and providing good quality housing on secure tenancy terms. In other countries, in which a typical example is the U.K., social housing is seen as a safety net for the relatively poor which is segregated from the private rental market and therefore is formed as a stigmatized and often means-tested sector. Private rented housing is usually expensive providing little security. As a result, owner-occupation is fostered. Finally, there are countries like Greece, Italy and Spain, which encourage homeownership. The rental market has been reduced considerably as the result of legislations, which lowered the attractiveness of renting as an investment, leaving owner occupation as the only option for housing. The distribution of tenure across countries can be also affected by the extent to which legal enforcement of contracts is costly. Casas-Arce and Saiz (2006), show that costly enforcement of rental contracts hampers the development of rental housing market.

How does the ownership rate relate with age? Do households hold on their housing as they get older? Figure $2 \mathrm{a}$ and $2 \mathrm{~b}$ present tenure rates by age groups and by country. For each country, every column represents the share between owners and renters of a particular age group. For Austria, Belgium, Denmark, Netherlands, and the U.K., homeownership rates seem to decline with age, while for Finland, France, Greece, and Italy, a hump shape is observed with increasing ownership rates up to 70 years old and a decline above 70 . For Germany, Portugal, and Spain, homeownership remains relatively constant with some decline in Germany and Spain at older ages.

Cohort effects might affect the tenure rates for the older age groups. That is, if older cohorts had lower lifetime income, this would result in lower homeownership rates which would appear as a decline of ownership with age in Figure 2a and 2b. To take into account possible cohort effects, Figure 3 plots ownership rates across time by cohort and by country, where cohorts are defined by their age at the first wave. That is, Cohort 50 refers to those who are 50 years old in 1994, Cohort 58 to those who are 58 etc. Jumps in the ownership rates across cohorts indicate the presence of cohort effects. The general pattern shows increasing ownership rates between 50-57 years old, constant rates around retirement age, and some 
decline at older age. This decline is evident for Germany, Denmark, the U.K. and the Netherlands.

The evidence provided so far suggests that there is some decline in homeownership as people age, which is more pronounced in some countries than others. Adjustment of housing typically requires turnover which is reflected on residential mobility rates. The next section focuses on the mobility rate of older households across countries by age and by housing tenure.

\section{Residential Mobility}

Residential mobility is less common in the southern compared to the central and northern Europe. As Figure 4 shows, mobility rates in Greece, Italy, Portugal, and Spain, vary between 1 to 1.5 per cent, while they are much higher in Denmark, Finland, and Germany, around 4 per cent, and somewhat in between these rates for Belgium, France, U.K., and the Netherlands. Mobility rates also differ between owners and renters, as Figure 5 shows, with households who own their house moving less than renters. Renters move between 3 to 5 times more than owners, while the difference in mobility between owners and renters is lower in Denmark, U.K., and the Netherlands. One of the reasons for the low mobility rates of homeowners is related to the cost of selling and buying of housing. However, ownership versus renting can also be considered as an endogenous decision. As argued by Sinai and Souleles (2005), there is a trade-off: renters face fluctuations of the rental price, while owners face the price risk for selling if they decide to move. Therefore, those users who are likely to stay in the current location will decide to become owners, while those who are likely to move will become renters. Overall, there seems to be a negative relationship between the homeownership rates of Figure 1 and the mobility rates of Figure 5. In countries with higher ownership rates mobility is lower.

Mobility rates across age groups are depicted in Figure 6a. Starting from high rates at 50-54 years old, mobility rates decline in subsequent age groups up to around 70 years old, and remain constant, or appear to increase slightly for those above 70 . This seems to be the case mostly in northern European countries, while in countries like Greece, Portugal, and Spain, a decline in mobility is observed as people age. Figure $6 \mathrm{~b}$ presents the mobility rates across age only for the homeowners showing a similar pattern as for the whole sample in Figure 6a. That is, homeowners seem to experience increased mobility above 70 years old which drives the slowdown, or the slight increase, of mobility rates for all the households in Figure 6a. 
Decreasing homeownership rates and increasing mobility rates provide some indication for the validity of the Life Cycle Hypothesis (LCH). As pointed out by Hurd (1990, pp.624), if the desired housing consumption falls with age as specified by the $\mathrm{LCH}$, the difference between actual and desired consumption will eventually become large to overcome transaction costs and a move will occur. The following section investigates further the effect of age and ownership on mobility, taking into account other determinants such as retirement, changes in the family structure, income, wealth, type of housing etc.

\subsection{The Determinants of Residential Mobility}

Table 1 contains the estimates from a logit model with the dependent variable which equals to one if a residential move occurs within the period between two consecutive years, and zero otherwise. The specification includes a dummy for age above 65 years old, a dummy for being an owner, and an interaction of ownership with the age dummy. The interaction captures any differential effect of ownership across age. Other covariates include dummies for whether the head of the household, or the spouse, has retired during the previous year, whether the structure of the household has changed by the death of a spouse for couples, whether health had deteriorated within the last year, whether the household was living in an apartment in the last year, whether housing costs are a burden for the household, and the last year's household income and wealth. As wealth information is not very rich in the ECHP, property and capital income are used as proxies for wealth. Since the specification includes age and cohort effects, each regression allows as additional controls only regional dummies. ${ }^{5}$

The results from Table 1 show that homeowners are less likely to move compared to renters in all countries. The extent to which mobility of older owners differs from that of younger ones is depicted from the interaction of ownership with the age dummy. This interaction is positive and significant in Austria, Belgium, Denmark, Finland, France, Germany, Spain, and U.K., indicating that older owners are more likely to move compared to younger ones. For Greece, Ireland, Italy, Netherlands and Portugal, the interaction effect is not significant. Table 2 shows another specification with three age dummies: 65-69 years old, 70-74 years old, and 75 years old and above (reference group below 65 years old). The estimates for the interaction term suggest an increasing mobility for owners above 70 years

\footnotetext{
${ }^{5}$ All regressors refer to the first of the two years within which a move can take place, except for retirement which is defined as having retired in the previous year. The sample consists of all households which remain in the sample for at least two consecutive years and is restricted to those above 50 years old at the first observed wave. For couples, both members have to be above 50, while the observation of the head of the household is considered in the sample.
} 
old. Two events during the lifetime which can induce a residential move are retirement and the death of the spouse. The results from Table 1 indicate that retiring significantly increases the likelihood to move in Germany and the U.K., but has a negative effect in the Netherlands. The death of a spouse has a significant and positive effect in Denmark, France, Finland, Germany, and Spain.

Table 3 shows pooled country estimates of the logit estimation grouping countries in two broad groups based on the results from Table 1. The first group called "North" consists of Austria, Belgium, Denmark, Finland, France, Germany, Ireland, and Netherlands, and the second group called “South” consists of Greece, Italy, Spain, and Portugal. Although owners are less likely to move in all countries, older owners above 65 years old are significantly more likely to move in the North, but not in the South. ${ }^{6}$ Moreover, having an outstanding home loan, retirement, the death of a spouse, and excessive housing costs, are significantly associated with a move in the North, but not in the South. Finally, households with higher wealth holdings are more likely to move in all countries.

\section{Housing Adjustment}

\subsection{Tenure Transitions}

Adjustment of actual to desired housing can be achieved with transitions from ownership to tenancy, or by reducing the size and/or the value of the house for those who remain owners. Since information on the house values before and after the move is not available, the following analysis will be focused on the housing tenure transitions and on the changes in the home size as a way to analyze housing adjustment.

Table 4 presents the housing transition rates within two consecutive years for the owners who move by age groups. Due to the small cell size for each age group in each country the transitions are presented by the group of countries as defined above. For the countries in the North (South), about 67 per cent (75 per cent) of owners who move above 50 years old remain owners after the move. Distinguishing between different age groups, Table 4 shows that the percentage of owners who move and become renters is increasing with age. The rate of increase is much higher in the North especially for those above 75 years old compared to the South. Table 5 presents the change on the size of home for owner households who move and remain owners. Based both on the actual home size and the adjusted size for

\footnotetext{
${ }^{6}$ It is only in the specification with the three age groups that owners in the South above 75 years old have a positive and significant coefficient. From Table 1 this effect is shown to be due to Spain.
} 
the number of members in the household, the share of households who reduce housing size upon moving is higher in the North compared to the South.

\subsection{Competing Risk Hazard Model}

To investigate the transitions out of the current tenure choice in a multivariate setting controlling for household characteristics, a competing risk hazard model of housing tenure is estimated. The model distinguishes between transitions from the current tenure choice to ownership (o) and transitions to renting $(r)$, allowing for different effect of the household characteristics on each choice.

The analysis is based on the first observed housing tenure spell in the data. The housing tenure duration is measured in years as the difference between the year in which the household experiences a move from the current residence and the year in which it has moved at the current residence. Households that do not move are treated as right censored. All households at their first interview are already in the initial state, that is, they are either owners or renters. This stock sampling might lead to sample selection bias, as only households who have survived in the current residence are observed, which tends to over-represent longer tenured households. To take into account this source of bias the likelihood function is modified conditioning on the fact that the household has survived in the current state up to the initially observed time.

Each destination specific hazard $j=o, r$ is the product of the baseline hazard, which captures the time dependence in the hazard rate, a function of observed characteristics $X_{i}$, and unobserved characteristics, $v_{j}$. The hazard can be written as:

$$
\theta_{j}\left(t \mid X_{i}, v_{j}\right)=\lambda_{j}(t) \exp \left(X^{\prime}(t) \beta_{j}+v_{j}\right)
$$

where $\lambda_{j}(t)$ is the baseline hazard and $\exp \left(X^{\prime}(t) \beta_{j}+v_{j}\right)$ is the systematic part of the hazard. The baseline hazard is specified flexibly as both $\lambda_{o}(t)$ and $\lambda_{r}(t)$ have a piecewise constant specification, such that they are constant within duration intervals. The conditional density function of the completed tenure duration $\tau_{h}$ is given by

$$
f_{j}\left(\tau_{h} \mid X_{i}, v_{j}\right)=\theta_{j}\left(\tau_{h} \mid .\right) \exp \left(-\int_{0}^{\tau_{h}} \theta_{j}(s \mid .) d s\right)
$$


Letting $c_{j}$ be the destination indicator variables for the tenure duration, which also take into account right-censoring, the individual contribution to the likelihood function is

$$
L=\int_{v_{o}} \int_{v_{r}}\left(\left[f_{j}\left(\tau_{j} \mid .\right)\right]^{c_{j}}\left[1-F_{j}\left(\tau_{j} \mid .\right)\right]^{1-c_{j}}\right)\left[1-F_{j}(b-a \mid .)\right]^{-1} d G\left(v_{o}, v_{r}\right)
$$

where $G\left(v_{o}, v_{r}\right)$ is the joint cdf of the unobservables. Using the flexible and widely applied specification based on Heckman and Singer (1984) the unobserved factors $v_{o}$ and $v_{r}$ are assumed to follow a discrete distribution with two points of support. Van den Berg (2001) provides a detailed discussion of identification issues of the mixed proportional hazard model.

The third part of equation (3) accounts for the left censoring which occurs because the sampled households are in the initial state at the point of sampling $b$. Households enter the current state at time $a$ but are observed in the sample, if and only if, they are still at the initial state at time $b$. Therefore, the observed duration must be greater, or at least, equal to $b-a$. The correct conditioning likelihood function is obtained by dividing with the probability of duration to be greater than $b-a$, i.e. $\operatorname{prob}\left(\tau_{h} \geq b-a \mid.\right)=1-F_{j}(b-a \mid$.$) Equation (3) can$ be also written as:

$$
\begin{aligned}
& L=\int_{v_{o}} \int_{v_{r}} \theta_{o}\left(\tau_{h} \mid .\right)^{c_{o}} \theta_{r}\left(\tau_{h} \mid .\right)^{c_{r}} \\
& \cdot \exp \left(-\int_{0}^{\tau_{h}} \theta_{o}(s \mid .) d s--\int_{0}^{\tau_{h}} \theta_{r}(s \mid .) d s-\int_{b}^{a} \theta_{o}(s \mid .) d s-\int_{b}^{a} \theta_{r}(s \mid .) d s\right) d G\left(v_{o}, v_{r}\right)
\end{aligned}
$$

The probability for the household to change residence and become either an owner or a tenant at a particular year, given that the household has not moved up to that year, is a function of the time spent in the current residence, the type of tenure, the family and household characteristics, and the changes in these characteristics. For the characteristics that vary with time the specification includes, similarly with the discrete choice model of the previous section, a dummy for becoming retired, a dummy for the death of the spouse, and a dummy for the changes in the health status. ${ }^{7}$

\footnotetext{
${ }^{7}$ For instance, the dummy for retirement is equal to one if retirement occurs within the observation period, and zero otherwise. For those who retire the value remains one for the years following retirement. The construction for the death of the spouse and the health status follows similarly.
} 


\subsection{Empirical Results on Housing Transitions}

Table 6 presents the coefficient estimates of the competing risk hazard model estimated separately for each country, focusing on the ownership dummy and its interaction with age. ${ }^{89}$ The results indicate that in all countries (except in Ireland) owners are less likely to become renters once they exit from their current residence compared to renters. To identify whether transitions from ownership depend on age, the model allows for the interaction of the homeownership dummy with the dummy for age above 65 years. This coefficient of the interaction effect for the transition towards renting is positive and significant in Germany, Italy, and Spain. Estimating the model allowing for different age groups, Table 7 shows a significant and positive effect of being an owner above 75 years old on the transitions towards renting for Finland, France, Germany, Italy, Spain, and the U.K. The coefficient of the interaction term is also positive in the rest of the countries, but not significantly different than zero. Due to the small cell size, this specification was not possible to be estimated for all the countries.

Similarly with the logit model, in the previous section, the competing risk hazard model was estimated on the pooled sample of countries. This pooling provides with enough variation to estimate the model separately for couples and singles. ${ }^{10}$ The first panel of Table 8 , which refers to all countries, shows an increasing exit rate of older home owners from the current residence both for couple and single households. The direction of the transition is both towards remaining owner and becoming a renter. The second panel of Table 8 shows a higher exit rate of older owners towards ownership compared to renting for the countries in the North group. In the South, older owners have higher exit rates towards renting with the effect being significant at the 10 per cent level, and a larger effect for single households.

These results indicate that, after controlling for the effect of other characteristics such as retirement, health deterioration, changes in the family structure and cohort effects, although owners are less likely to move, there is an increasing transition out of the current residence for older owners. The direction of the transition is mostly from ownership to renting. However,

\footnotetext{
${ }^{8}$ The coefficient estimates for the other covariates are presented in Table A1 in the appendix. As cohort, time, and age effects, cannot be jointly identified, the analysis focuses on cohort and age effects, similarly with Churi and Japelli (2006).

${ }_{9}^{9}$ Unobserved heterogeneity was identified for Belgium, Germany, Greece, and the U.K., but it was not significant. Although a formal test is not available as the two models, with and without heterogeneity, are not nested, the difference of the likelihood values was very small. For the rest of the countries unobserved heterogeneity was not identified. These results are available from the author upon request.

${ }^{10}$ Hurd (1999) shows that the rate of wealth decumulation by couples will change with age, as it depends on the ages of both spouses and on the economic circumstances facing each after widowing.
} 
especially in countries in northern Europe, there are also transitions from ownership to ownership, which have been shown to be associated with a reduction in the home size (Table 5). These transitions suggest that dissaving occurs later in life which is in line with the LifeCycle Hypothesis.

\section{Conclusions}

In this paper the determinants of residential mobility and the housing adjustment decisions of older households are investigated for Europe employing data from the European Community Household Panel (1994-2001). Housing is one of the most important components of wealth for a large part of the older population. Changes in the family structure, the financial situation, and the physical needs as people age create a gap between the desired and the current housing consumption.

While housing adjustment typically requires a move, residential mobility rates of older age households are rather low, particularly in the southern than in central or northern Europe. Regarding the determinants of residential mobility, although homeowners are less likely to move compared to renters, an increase in mobility rates is observed for older age homeowners. The positive effect of age on mobility, for homeowners, is in line with the prediction of the LCH according to which there should be a decline of the desired housing consumption with age, which results in a move. Moreover, having an outstanding home loan, retirement, the death of a spouse, and excessive housing costs, are significantly associated with a move in central and northern European countries, but not in the south.

Analyzing the transitions from the current tenure choice after a move takes place based on a competing risk hazard model, it is found that there is an increasing transition out of the current residence for older households indicating some dissaving later in life. The direction of the transitions is mostly towards renting. However, especially in countries in central and northern Europe there are also transitions from ownership to ownership, which are associated with a reduction in the home size. 


\section{References}

Balchin, P. (1996): "Housing Policy in Europe" (eds.), Routledge, London.

Börsch-Supan, A. (1994): "Aging in Germany and the United States: International

Comparisons", in Wise, D.A. (eds.), Studies in the Economics of Aging, University of Chicago Press.

Casas-Arce, P. and Albert Saiz (2006): "Owning versus Leasing: Do Courts Matter? ", mimeo.

Ermisch, J.F. and Jenkins, S.P. (1999): "Retirement and housing adjustment in later life: evidence from the British Household Panel Survey", Labour Economics, 6, pp. 311-333.

Feinstein, J. and McFadden, D. (1989): "The Dynamics of Housing Demand by the Elderly:

Wealth, Cash Flow, and Demographic Effects", in D.Wise (eds), The Economics of Aging, University of Chicago Press.

European Commission (2001): "High Level Task Force on Skills and Mobility", Final report. European Commission (2003): "Jobs, Jobs, Jobs: Creating more employment in Europe".

Report of the Employment Taskforce.

Hurd, M.D. (1990): "Research on the Elderly: Economic Status, Retirement, and Consumption and Saving", Journal of Economic Literature, vol. 28, No.2, pp. 565-637. Hurd, M.D. (1999): "Mortality Risk and Consumption by Couples", NBER Working Paper No. 7048.

Churi, M.C. and T. Japelli (2006): "Do the Elderly Reduce Housing Equity? An International Comparison", CSEF Working Paper No. 158.

Merrill, S.R. (1984): "Home Equity and the Elderly", in H. Aaron and G. Burtless (eds), Retirement and Economic Behavior, Brookings Institution.

Mitchell, O.S. and Piggott, J. (2004): "Unlocking housing equity in Japan", NBER Working Paper No. 10340.

Sinai, T. and N. Souleles (2005): "Owner-Occupied Housing as a Hedge Against Rent Risk",

The Quarterly Journal of Economics, 120(2), pp. 763-789.

Sheiner, L. and Weil, D. (1993): "The Housing Wealth of the Aged", NBER Working Paper No. 4415.

Van den Berg, G.J. (2001): "Duration Models: Specification, Identification, and Multiple Durations", in: Heckman J. and Leamer, E. (Eds.), Handbook of Econometrics, Vol. V, North-Holland, Amsterdam, pp. 3381-3460.

Venti, S.F. and Wise D.A. (2002): "Aging and Housing Equity", in Innovation in Retirement Financing, Z. Bodie, P. Hammond and O. Mitchell eds. Philadelphia: University of 
Pennsylvania Press.

Venti, S.F. and Wise D.A. (2004), "Aging and Housing Equity: Another Look", in Perspective in the Economics of Aging, Chicago: University of Chicago Press.

Wooldridge, J.M. (2002). "Econometric Analysis of Cross Section and Panel Data". MIT Press. 


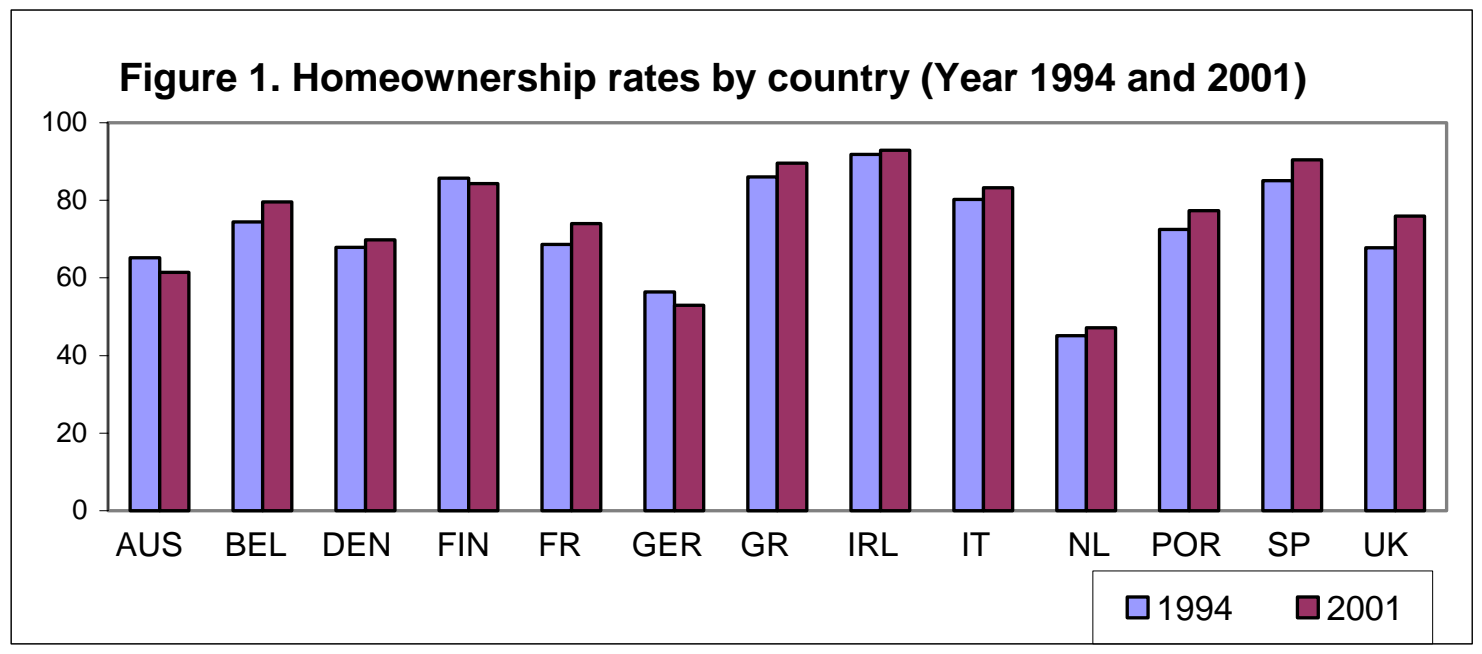

Figure $2 a$. Housing tenure rates by country and age groups (\%)

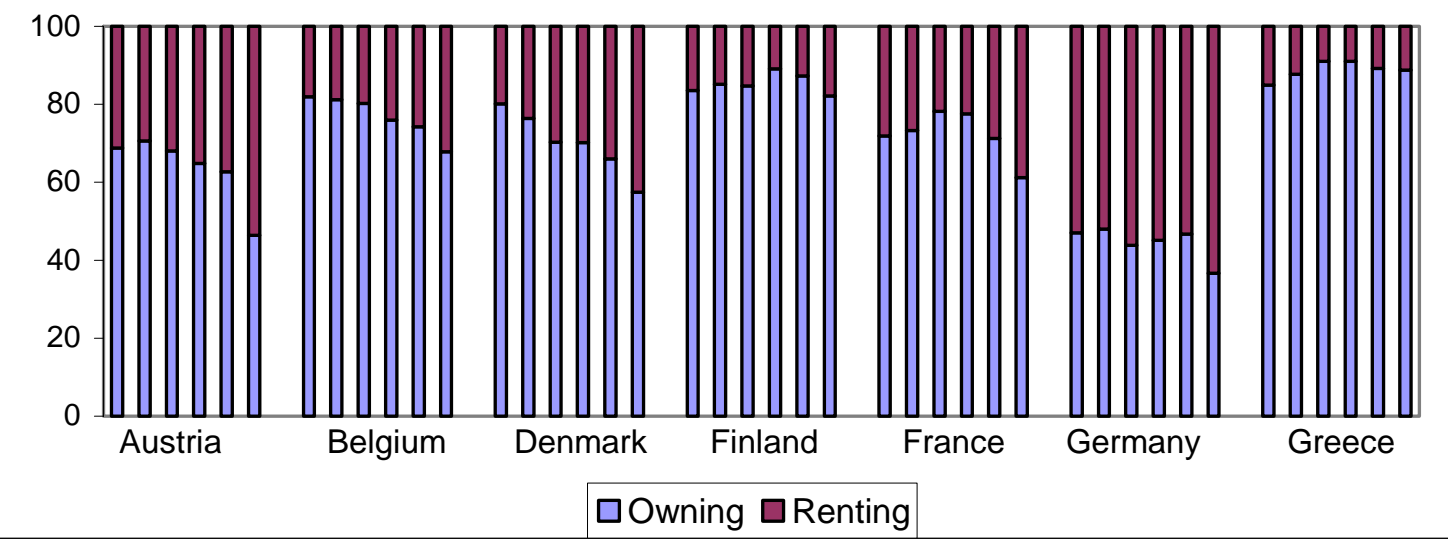

Figure $\mathbf{2 b}$. Housing tenure rates by country and age groups (\%)

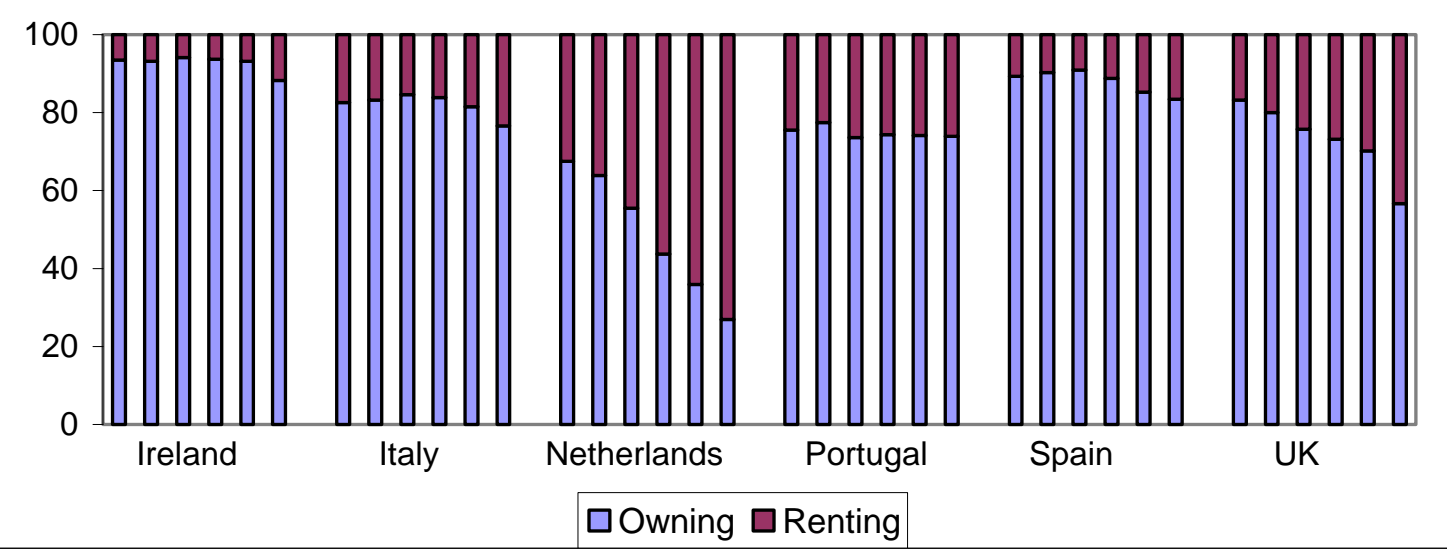

Source: ECHP (1994-2001). Own calculations. 

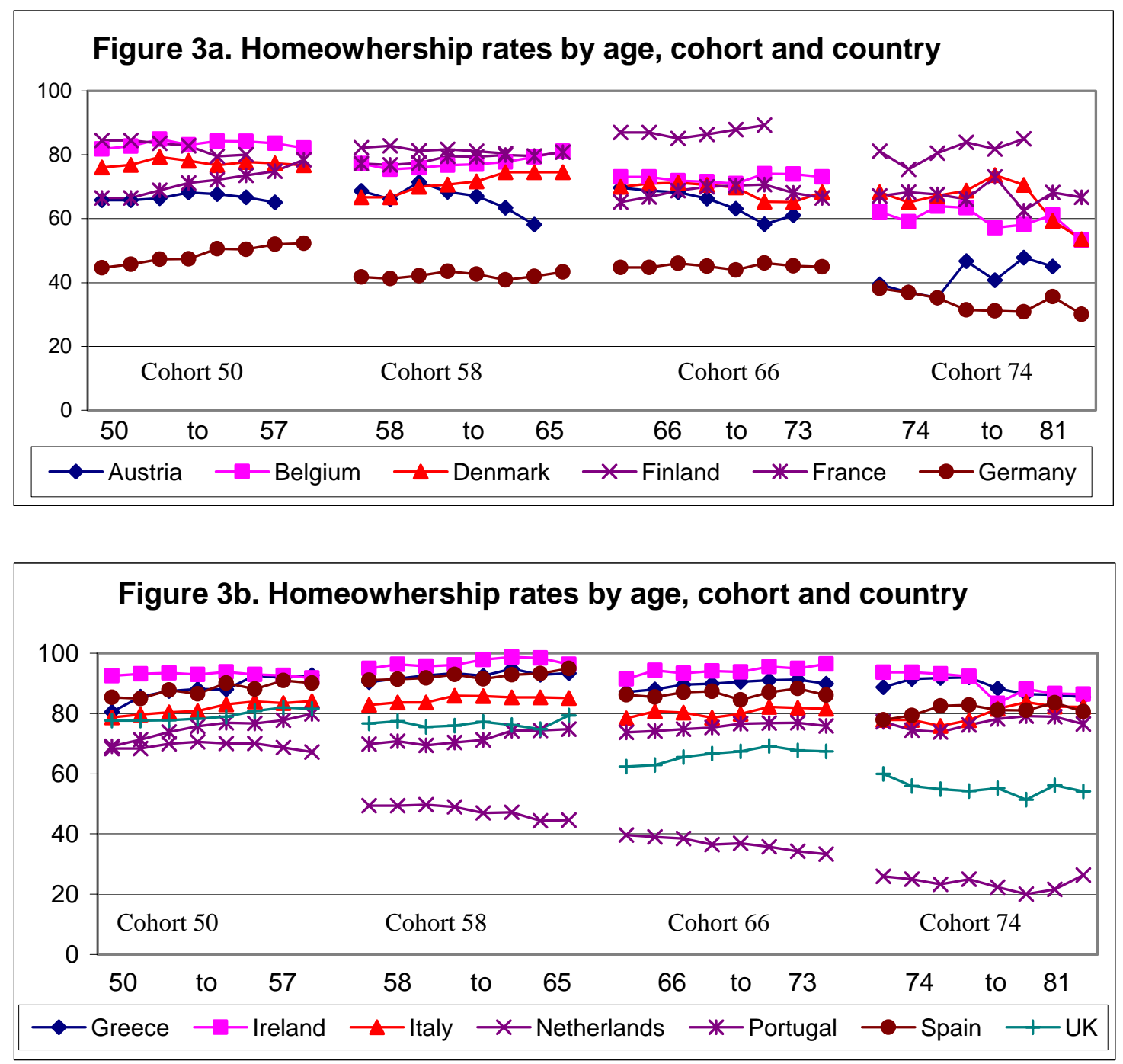

Source: ECHP (1994-2001). Own calculations. 
Figure 4. Mobility rates by country

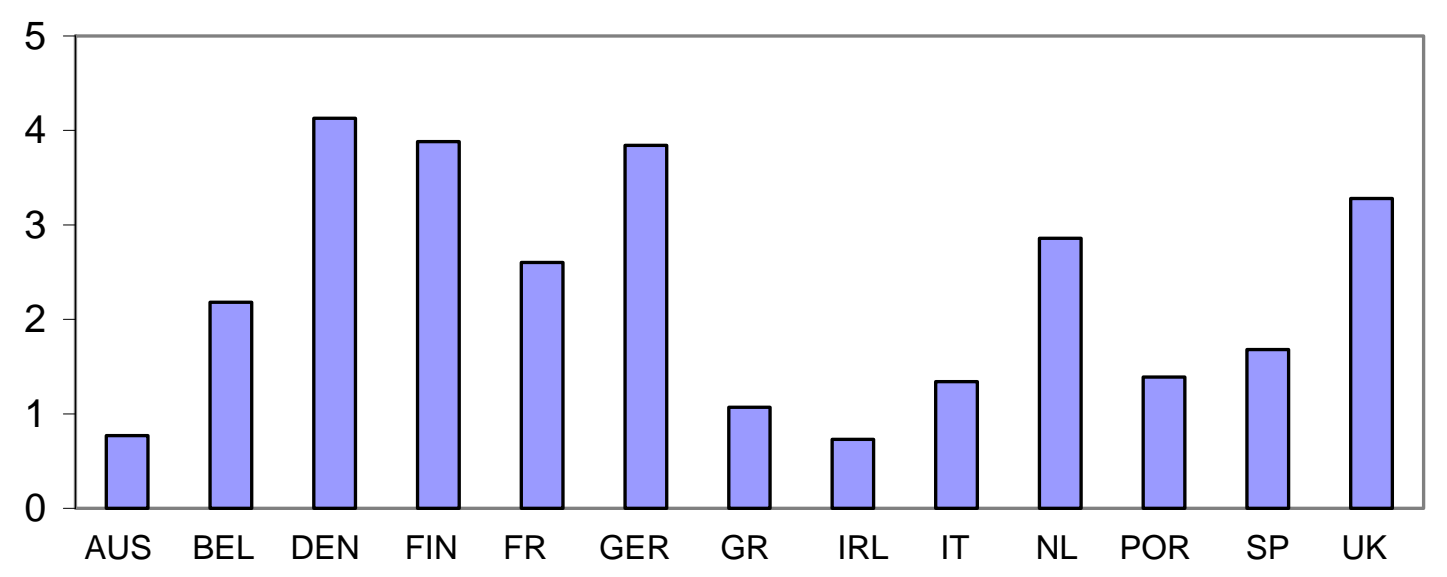

Figure 5. Mobility rates by housing tenure and by country

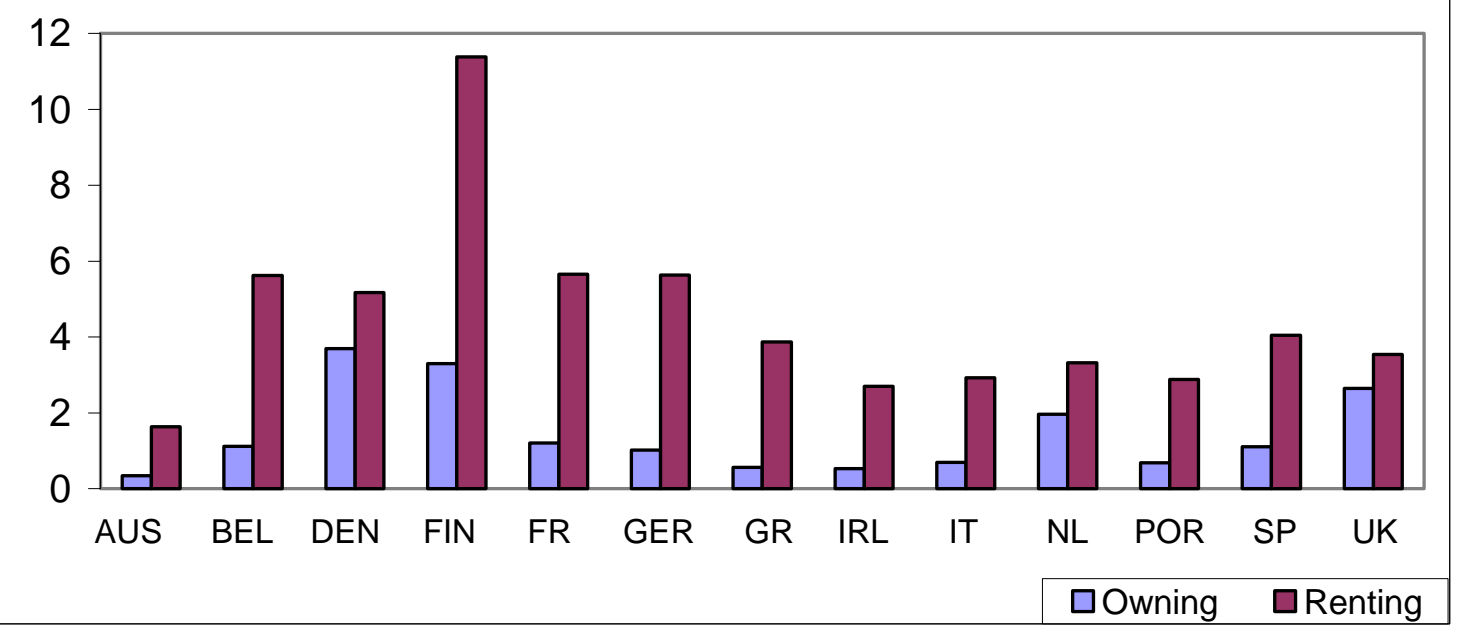

Source: ECHP (1994-2001). Own calculations. 

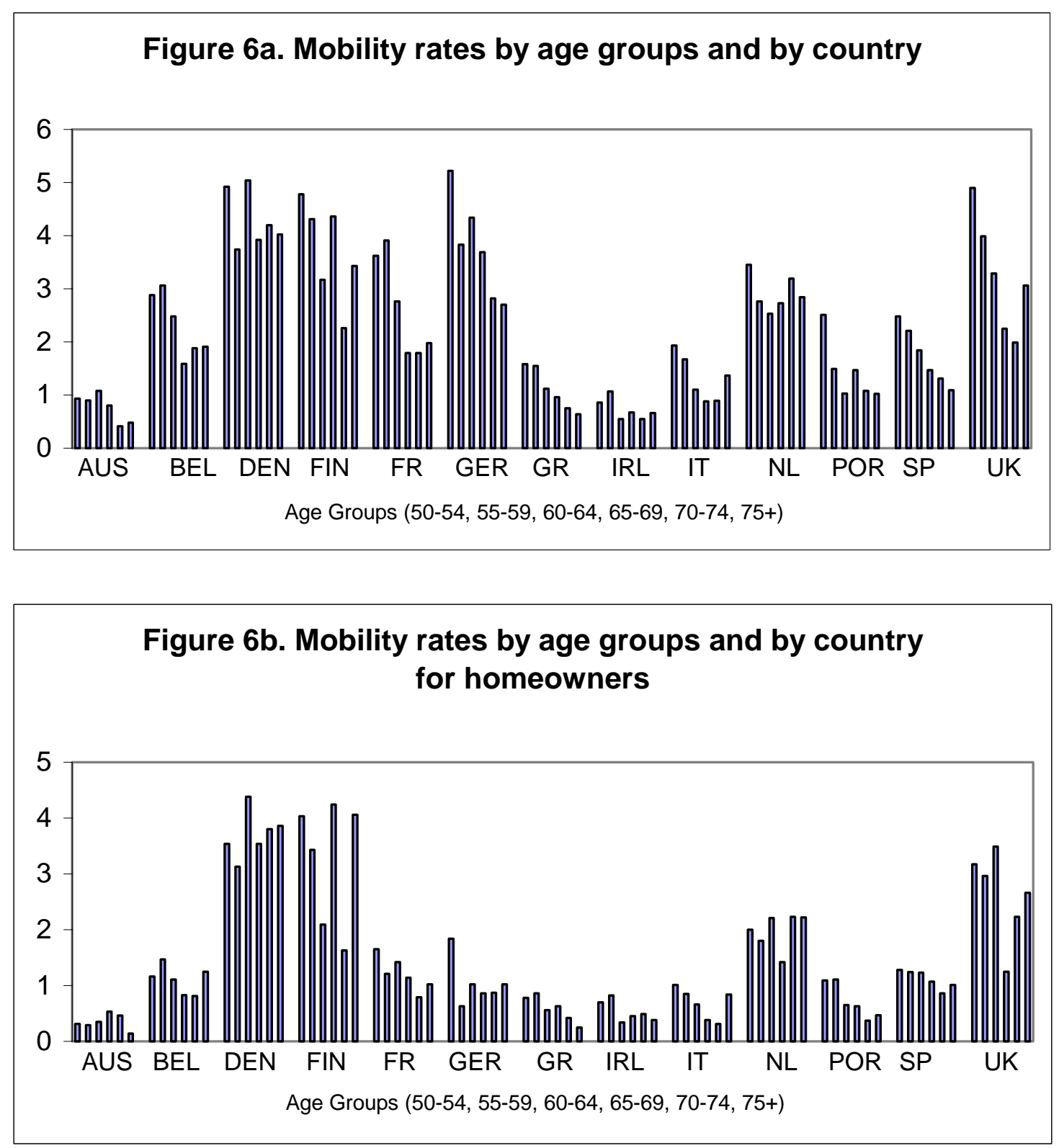

Source: ECHP (1994-2001). Own calculations. 


\begin{tabular}{|c|c|c|c|c|c|c|c|c|c|c|c|c|c|}
\hline & Austria & Belgium & Denmark & Finland & France & Germany & Greece & Ireland & Italy & Netherlands & Portugal & Spain & UK \\
\hline Age $65+$ & $\begin{array}{c}-0.826 \\
(0.572)\end{array}$ & $\begin{array}{c}-1.212^{* * *} \\
(0.334)\end{array}$ & $\begin{array}{c}-0.783 * * * \\
(0.294)\end{array}$ & $\begin{array}{c}-0.161 \\
(0.346)\end{array}$ & $\begin{array}{c}-0.701^{* * *} \\
(0.241)\end{array}$ & $\begin{array}{l}-0.067 \\
(0.171)\end{array}$ & $\begin{array}{c}-0.185 \\
(0.399)\end{array}$ & $\begin{array}{c}0.720 \\
(0.855)\end{array}$ & $\begin{array}{c}-0.500 \\
(0.314)\end{array}$ & $\begin{array}{c}-0.268 \\
(0.230)\end{array}$ & $\begin{array}{c}0.527 * \\
(0.284)\end{array}$ & $\begin{array}{c}-1.263 * * * \\
(0.327)\end{array}$ & $\begin{array}{c}-1.641^{* * *} \\
(0.307)\end{array}$ \\
\hline Owner & $\begin{array}{c}-1.645^{* * *} \\
(0.511)\end{array}$ & $\begin{array}{c}-2.741 * * * \\
(0.388)\end{array}$ & $\begin{array}{c}-0.945 * * * \\
(0.291)\end{array}$ & $\begin{array}{c}-1.833^{* * *} \\
(0.218)\end{array}$ & $\begin{array}{c}-1.988 * * * \\
(0.212)\end{array}$ & $\begin{array}{c}-2.214 * * * \\
(0.284)\end{array}$ & $\begin{array}{c}-2.017 * * * \\
(0.270)\end{array}$ & $\begin{array}{c}-1.593 * * * \\
(0.526)\end{array}$ & $\begin{array}{c}-1.614 * * * \\
(0.224)\end{array}$ & $\begin{array}{l}-0.406 \\
(0.286)\end{array}$ & $\begin{array}{c}-1.162 * * * \\
(0.261)\end{array}$ & $\begin{array}{c}-1.867 * * * \\
(0.208)\end{array}$ & $\begin{array}{c}-0.549 * * \\
(0.248)\end{array}$ \\
\hline Owner*(Age 65+) & $\begin{array}{l}1.143^{*} \\
(0.631)\end{array}$ & $\begin{array}{c}1.464^{* * *} \\
(0.435)\end{array}$ & $\begin{array}{c}0.694 * * \\
(0.284)\end{array}$ & $\begin{array}{c}0.822 * * * \\
(0.310)\end{array}$ & $\begin{array}{l}0.536^{* *} \\
(0.249)\end{array}$ & $\begin{array}{l}0.594 * \\
(0.326)\end{array}$ & $\begin{array}{c}0.208 \\
(0.385)\end{array}$ & $\begin{array}{c}0.088 \\
(0.749)\end{array}$ & $\begin{array}{l}-0.003 \\
(0.320)\end{array}$ & $\begin{array}{l}-0.194 \\
(0.287)\end{array}$ & $\begin{array}{l}-0.386 \\
(0.332)\end{array}$ & $\begin{array}{c}1.047^{* * *} \\
(0.285)\end{array}$ & $\begin{array}{l}0.508^{*} \\
(0.291)\end{array}$ \\
\hline Outstanding Loan & $\begin{array}{l}-1.645 \\
(1.004)\end{array}$ & $\begin{array}{l}0.802^{*} \\
(0.436)\end{array}$ & $\begin{array}{c}0.133 \\
(0.212)\end{array}$ & $\begin{array}{l}0.366^{*} \\
(0.197)\end{array}$ & $\begin{array}{l}-0.189 \\
(0.256)\end{array}$ & $\begin{array}{c}0.245 \\
(0.312)\end{array}$ & $\begin{array}{c}0.278 \\
(0.412)\end{array}$ & $\begin{array}{c}0.780^{* *} \\
(0.393)\end{array}$ & $\begin{array}{c}0.004 \\
(0.370)\end{array}$ & $\begin{array}{l}-0.033 \\
(0.248)\end{array}$ & $\begin{array}{l}-0.449 \\
(0.528)\end{array}$ & $\begin{array}{l}-0.276 \\
(0.300)\end{array}$ & $\begin{array}{c}0.118 \\
(0.187)\end{array}$ \\
\hline Retired & $\begin{array}{c}0.054 \\
(0.381)\end{array}$ & $\begin{array}{l}-0.369 \\
(0.276)\end{array}$ & $\begin{array}{c}0.182 \\
(0.180)\end{array}$ & $\begin{array}{c}0.176 \\
(0.204)\end{array}$ & $\begin{array}{c}0.250 \\
(0.175)\end{array}$ & $\begin{array}{c}0.330 * * * \\
(0.116)\end{array}$ & $\begin{array}{c}0.035 \\
(0.250)\end{array}$ & $\begin{array}{c}0.431 \\
(0.403)\end{array}$ & $\begin{array}{c}0.077 \\
(0.191)\end{array}$ & $\begin{array}{c}-0.723^{* *} \\
(0.335)\end{array}$ & $\begin{array}{c}0.267 \\
(0.185)\end{array}$ & $\begin{array}{c}0.024 \\
(0.183)\end{array}$ & $\begin{array}{c}0.365^{* *} \\
(0.162)\end{array}$ \\
\hline Spouse Retired & $\begin{array}{l}-1.643 \\
(1.036)\end{array}$ & $\begin{array}{c}0.159 \\
(0.318)\end{array}$ & $\begin{array}{l}0.404 * * \\
(0.204)\end{array}$ & $\begin{array}{c}0.096 \\
(0.266)\end{array}$ & $\begin{array}{c}0.184 \\
(0.219)\end{array}$ & $\begin{array}{l}-0.088 \\
(0.155)\end{array}$ & $\begin{array}{l}-0.496 \\
(0.438)\end{array}$ & $\begin{array}{l}-0.042 \\
(0.722)\end{array}$ & $\begin{array}{c}0.128 \\
(0.290)\end{array}$ & $\begin{array}{l}-0.639 \\
(0.564)\end{array}$ & $\begin{array}{l}0.383^{*} \\
(0.209)\end{array}$ & $\begin{array}{l}0.482 * * \\
(0.207)\end{array}$ & $\begin{array}{c}0.005 \\
(0.197)\end{array}$ \\
\hline Loss of Spouse & $\begin{array}{c}0.434 \\
(0.762)\end{array}$ & $\begin{array}{c}0.416 \\
(0.416)\end{array}$ & $\begin{array}{c}0.953 * * * \\
(0.257)\end{array}$ & $\begin{array}{c}1.334^{* * * *} \\
(0.270)\end{array}$ & $\begin{array}{c}0.779 * * * \\
(0.287)\end{array}$ & $\begin{array}{l}0.609 * * \\
(0.241)\end{array}$ & $\begin{array}{l}-0.265 \\
(0.639)\end{array}$ & $\begin{array}{c}1.012 \\
(0.890)\end{array}$ & $\begin{array}{c}0.023 \\
(0.466)\end{array}$ & $\begin{array}{c}0.386 \\
(0.272)\end{array}$ & $\begin{array}{c}0.175 \\
(0.393)\end{array}$ & $\begin{array}{c}0.765^{* *} \\
(0.311)\end{array}$ & $\begin{array}{c}0.125 \\
(0.291)\end{array}$ \\
\hline Health Shock & $\begin{array}{c}0.063 \\
(0.336)\end{array}$ & $\begin{array}{c}0.149 \\
(0.222)\end{array}$ & $\begin{array}{l}-0.032 \\
(0.164)\end{array}$ & $\begin{array}{l}-0.018 \\
(0.177)\end{array}$ & $\begin{array}{l}-0.115 \\
(0.155)\end{array}$ & $\begin{array}{c}-0.262^{* *} \\
(0.128)\end{array}$ & $\begin{array}{c}0.269 \\
(0.226)\end{array}$ & $\begin{array}{l}-0.062 \\
(0.391)\end{array}$ & $\begin{array}{l}0.351 * * \\
(0.177)\end{array}$ & $\begin{array}{c}0.111 \\
(0.160)\end{array}$ & $\begin{array}{l}0.389 * * \\
(0.194)\end{array}$ & $\begin{array}{l}-0.331 * \\
(0.178)\end{array}$ & $\begin{array}{l}0.321^{* *} \\
(0.136)\end{array}$ \\
\hline Health Shock - Spouse & $\begin{array}{l}0.763^{* *} \\
(0.377)\end{array}$ & $\begin{array}{c}0.077 \\
(0.303)\end{array}$ & $\begin{array}{c}0.135 \\
(0.218)\end{array}$ & $\begin{array}{l}-0.243 \\
(0.245)\end{array}$ & $\begin{array}{l}-0.090 \\
(0.194)\end{array}$ & $\begin{array}{c}0.109 \\
(0.148)\end{array}$ & $\begin{array}{c}0.203 \\
(0.246)\end{array}$ & $\begin{array}{c}0.243 \\
(0.459)\end{array}$ & $\begin{array}{l}-0.327 \\
(0.252)\end{array}$ & $\begin{array}{c}0.084 \\
(0.207)\end{array}$ & $\begin{array}{c}0.150 \\
(0.237)\end{array}$ & $\begin{array}{c}0.040 \\
(0.184)\end{array}$ & $\begin{array}{l}-0.306 \\
(0.215)\end{array}$ \\
\hline Presence of Children & $\begin{array}{c}0.042 \\
(0.635)\end{array}$ & $\begin{array}{l}-0.365 \\
(0.632)\end{array}$ & $\begin{array}{c}0.067 \\
(0.516)\end{array}$ & $\begin{array}{l}-0.488 \\
(0.393)\end{array}$ & $\begin{array}{l}-0.016 \\
(0.280)\end{array}$ & $\begin{array}{l}0.523 * * \\
(0.232)\end{array}$ & $\begin{array}{c}0.616^{* *} \\
(0.277)\end{array}$ & $\begin{array}{l}-0.485 \\
(0.649)\end{array}$ & $\begin{array}{c}0.439 \\
(0.293)\end{array}$ & $\begin{array}{c}0.089 \\
(0.439)\end{array}$ & $\begin{array}{l}-0.038 \\
(0.331)\end{array}$ & $\begin{array}{l}-0.031 \\
(0.278)\end{array}$ & $\begin{array}{l}-0.043 \\
(0.393)\end{array}$ \\
\hline Couple & $\begin{array}{l}-0.177 \\
(0.332)\end{array}$ & $\begin{array}{c}0.173 \\
(0.235)\end{array}$ & $\begin{array}{l}-0.096 \\
(0.188)\end{array}$ & $\begin{array}{l}-0.051 \\
(0.202)\end{array}$ & $\begin{array}{c}0.176 \\
(0.150)\end{array}$ & $\begin{array}{c}-0.556^{* * * *} \\
(0.125)\end{array}$ & $\begin{array}{c}0.625 \\
(0.381)\end{array}$ & $\begin{array}{l}-0.068 \\
(0.472)\end{array}$ & $\begin{array}{l}-0.387 * \\
(0.209)\end{array}$ & $\begin{array}{c}0.239 \\
(0.169)\end{array}$ & $\begin{array}{c}0.024 \\
(0.225)\end{array}$ & $\begin{array}{c}0.715^{* * * *} \\
(0.239)\end{array}$ & $\begin{array}{c}0.247 \\
(0.177)\end{array}$ \\
\hline Living in Appartment & $\begin{array}{c}0.518 \\
(0.347)\end{array}$ & $\begin{array}{c}0.260 \\
(0.255)\end{array}$ & $\begin{array}{l}-0.171 \\
(0.202)\end{array}$ & $\begin{array}{c}0.125 \\
(0.162)\end{array}$ & $\begin{array}{c}0.123 \\
(0.158)\end{array}$ & $\begin{array}{c}-0.307^{* * * *} \\
(0.114)\end{array}$ & $\begin{array}{l}0.513^{* *} \\
(0.228)\end{array}$ & $\begin{array}{c}0.935 \\
(0.617)\end{array}$ & $\begin{array}{c}0.058 \\
(0.181)\end{array}$ & $\begin{array}{l}-0.244 \\
(0.156)\end{array}$ & $\begin{array}{c}0.197 \\
(0.240)\end{array}$ & $\begin{array}{l}0.354^{* *} \\
(0.148)\end{array}$ & $\begin{array}{c}0.103 \\
(0.200)\end{array}$ \\
\hline Housing Cost a Burden & $\begin{array}{c}0.076 \\
(0.288)\end{array}$ & $\begin{array}{l}-0.195 \\
(0.193)\end{array}$ & $\begin{array}{l}0.257^{*} \\
(0.155)\end{array}$ & $\begin{array}{c}0.401^{* * * *} \\
(0.141)\end{array}$ & $\begin{array}{c}0.149 \\
(0.119)\end{array}$ & $\begin{array}{c}0.537 * * * \\
(0.112)\end{array}$ & $\begin{array}{c}0.586 * * * \\
(0.221)\end{array}$ & $\begin{array}{l}-0.293 \\
(0.328)\end{array}$ & $\begin{array}{l}0.485^{*} \\
(0.251)\end{array}$ & $\begin{array}{c}0.228 \\
(0.143)\end{array}$ & $\begin{array}{l}-0.145 \\
(0.163)\end{array}$ & $\begin{array}{c}0.071 \\
(0.177)\end{array}$ & $\begin{array}{c}0.105 \\
(0.292)\end{array}$ \\
\hline HH Income & $\begin{array}{l}-0.064 \\
(0.081)\end{array}$ & $\begin{array}{c}0.038 \\
(0.056)\end{array}$ & $\begin{array}{c}0.012 \\
(0.042)\end{array}$ & $\begin{array}{c}0.100 \\
(0.062)\end{array}$ & $\begin{array}{c}0.097 * * * \\
(0.026)\end{array}$ & $\begin{array}{l}0.097 * * \\
(0.040)\end{array}$ & $\begin{array}{c}0.086 \\
(0.067)\end{array}$ & $\begin{array}{l}-0.200 * \\
(0.118)\end{array}$ & $\begin{array}{c}0.038 \\
(0.050)\end{array}$ & $\begin{array}{l}-0.037 \\
(0.056)\end{array}$ & $\begin{array}{c}0.106 \\
(0.109)\end{array}$ & $\begin{array}{l}-0.0004 \\
(0.052)\end{array}$ & $\begin{array}{l}-0.034 \\
(0.057)\end{array}$ \\
\hline HH Wealth & $\begin{array}{c}0.104 \\
(0.125)\end{array}$ & $\begin{array}{l}-0.021 \\
(0.058)\end{array}$ & $\begin{array}{l}-0.215 \\
(0.246)\end{array}$ & $\begin{array}{l}0.147 * \\
(0.080)\end{array}$ & $\begin{array}{c}0.197 \\
(0.141)\end{array}$ & $\begin{array}{c}0.079 \\
(0.075)\end{array}$ & $\begin{array}{l}-0.448 \\
(0.421)\end{array}$ & $\begin{array}{c}0.352^{* *} \\
(0.155)\end{array}$ & $\begin{array}{c}0.237 \\
(0.163)\end{array}$ & $\begin{array}{l}-0.471 \\
(0.379)\end{array}$ & $\begin{array}{c}0.226 \\
(0.164)\end{array}$ & $\begin{array}{c}0.141 \\
(0.098)\end{array}$ & $\begin{array}{l}-0.061 \\
(0.170)\end{array}$ \\
\hline Cohort Effect & $\begin{array}{c}0.031 \\
(0.031)\end{array}$ & $\begin{array}{l}-0.003 \\
(0.016)\end{array}$ & $\begin{array}{l}-0.014 \\
(0.012)\end{array}$ & $\begin{array}{c}0.025 \\
(0.015)\end{array}$ & $\begin{array}{c}0.007 \\
(0.011)\end{array}$ & $\begin{array}{l}0.023 * * \\
(0.010)\end{array}$ & $\begin{array}{c}0.016 \\
(0.021)\end{array}$ & $\begin{array}{c}0.075^{* *} \\
(0.031)\end{array}$ & $\begin{array}{c}0.005 \\
(0.016)\end{array}$ & $\begin{array}{c}-0.022^{* *} \\
(0.011)\end{array}$ & $\begin{array}{c}0.048^{* *} \\
(0.019)\end{array}$ & $\begin{array}{c}-0.003 \\
(0.014)\end{array}$ & $\begin{array}{c}-0.051 \text { *** } \\
(0.012)\end{array}$ \\
\hline Constant & $\begin{array}{c}-4.247 * * * \\
(1.009)\end{array}$ & $\begin{array}{c}-2.300^{* * *} \\
(0.525)\end{array}$ & $\begin{array}{c}-2.265 * * * \\
(0.406)\end{array}$ & $\begin{array}{c}-3.213 * * * \\
(0.577)\end{array}$ & $\begin{array}{c}-3.350^{* * *} \\
(0.458)\end{array}$ & $\begin{array}{c}-4.065 * * * \\
(0.748)\end{array}$ & $\begin{array}{c}-4.872 * * * \\
(0.767)\end{array}$ & $\begin{array}{c}-6.524^{* * *} \\
(1.172)\end{array}$ & $\begin{array}{c}-4.264 * * * \\
(0.691)\end{array}$ & $\begin{array}{c}-2.892 * * * \\
(0.384)\end{array}$ & $\begin{array}{c}-5.541 * * * \\
(0.644)\end{array}$ & $\begin{array}{c}-3.452 * * * \\
(0.584)\end{array}$ & $\begin{array}{c}-1.556 * * * \\
(0.604)\end{array}$ \\
\hline $\begin{array}{l}\text { Log-Likelihood } \\
\text { Observations }\end{array}$ & $\begin{array}{c}-298.47 \\
7025\end{array}$ & $\begin{array}{c}-634.08 \\
7143\end{array}$ & $\begin{array}{c}-962.78 \\
5910\end{array}$ & $\begin{array}{c}-952.20 \\
6018\end{array}$ & $\begin{array}{c}-1351.76 \\
13795\end{array}$ & $\begin{array}{c}-1892.83 \\
14540\end{array}$ & $\begin{array}{l}-594.2 \\
14064\end{array}$ & $\begin{array}{c}-243.60 \\
7110\end{array}$ & $\begin{array}{c}-964.42 \\
17436\end{array}$ & $\begin{array}{c}-1246.49 \\
10971\end{array}$ & $\begin{array}{c}-860.17 \\
14960\end{array}$ & $\begin{array}{c}-1137.25 \\
16097\end{array}$ & $\begin{array}{c}-1287.99 \\
10783\end{array}$ \\
\hline
\end{tabular}




\begin{tabular}{|c|c|c|c|c|c|c|c|c|c|c|c|c|c|}
\hline & Austria & Belgium & Denmark & Finland & France & Germany & Greece & Ireland & Italy & Netherlands & Portugal & Spain & UK \\
\hline Age 65-69 & $\begin{array}{l}-0.790 \\
(0.542)\end{array}$ & $\begin{array}{c}-1.086 * * * \\
(0.387)\end{array}$ & $\begin{array}{c}-0.562 \\
(0.364)\end{array}$ & $\begin{array}{c}0.167 \\
(0.361)\end{array}$ & $\begin{array}{c}-0.883 * * * \\
(0.316)\end{array}$ & $\begin{array}{c}0.003 \\
(0.178)\end{array}$ & $\begin{array}{l}-0.232 \\
(0.483)\end{array}$ & $\begin{array}{c}1.009 \\
(0.841)\end{array}$ & $\begin{array}{l}-0.287 \\
(0.388)\end{array}$ & $\begin{array}{l}-0.363 \\
(0.253)\end{array}$ & $\begin{array}{c}0.669 * * \\
(0.313)\end{array}$ & $\begin{array}{c}-1.107 * * * \\
(0.385)\end{array}$ & $\begin{array}{c}-1.013 * * * \\
(0.384)\end{array}$ \\
\hline Age 70-74 & $\begin{array}{c}-1.770 * \\
(0.933)\end{array}$ & $\begin{array}{c}-0.999 * * \\
(0.449)\end{array}$ & $\begin{array}{l}-0.636 \\
(0.416)\end{array}$ & $\begin{array}{c}-0.441 \\
(0.518)\end{array}$ & $\begin{array}{c}-0.543^{*} \\
(0.287)\end{array}$ & $\begin{array}{l}-0.169 \\
(0.260)\end{array}$ & $\begin{array}{l}-0.323 \\
(0.521)\end{array}$ & $\begin{array}{c}0.855 \\
(1.196)\end{array}$ & $\begin{array}{l}-0.054 \\
(0.408)\end{array}$ & $\begin{array}{c}-0.257 \\
(0.295)\end{array}$ & $\begin{array}{c}0.622 \\
(0.424)\end{array}$ & $\begin{array}{c}-1.154^{* * *} \\
(0.405)\end{array}$ & $\begin{array}{c}-3.006 * * * \\
(0.768)\end{array}$ \\
\hline Age $75+$ & $\begin{array}{l}-1.704 \\
(1.090)\end{array}$ & $\begin{array}{c}-1.110 * * \\
(0.517)\end{array}$ & $\begin{array}{l}-0.595 \\
(0.465)\end{array}$ & $\begin{array}{c}-1.067 * \\
(0.573)\end{array}$ & $\begin{array}{c}-0.688 * \\
(0.394)\end{array}$ & $\begin{array}{l}-0.078 \\
(0.339)\end{array}$ & $\begin{array}{c}-0.387 \\
(0.778)\end{array}$ & & $\begin{array}{c}0.233 \\
(0.502)\end{array}$ & $\begin{array}{c}-0.663 \\
(0.415)\end{array}$ & $\begin{array}{c}0.747 \\
(0.482)\end{array}$ & $\begin{array}{c}-2.089 * * * \\
(0.588)\end{array}$ & $\begin{array}{c}-1.324 * * * \\
(0.449)\end{array}$ \\
\hline Owner & $\begin{array}{c}-1.642 * * * \\
(0.509)\end{array}$ & $\begin{array}{c}-2.758 * * * \\
(0.395)\end{array}$ & $\begin{array}{c}-0.998 * * * \\
(0.297)\end{array}$ & $\begin{array}{c}-1.845^{* * *} \\
(0.218)\end{array}$ & $\begin{array}{c}-1.984 * * * \\
(0.211)\end{array}$ & $\begin{array}{c}-2.238 * * * \\
(0.290)\end{array}$ & $\begin{array}{c}-2.019 * * * \\
(0.269)\end{array}$ & $\begin{array}{c}-1.621^{* * *} \\
(0.533)\end{array}$ & $\begin{array}{c}-1.601 * * * \\
(0.224)\end{array}$ & $\begin{array}{l}-0.418 \\
(0.288)\end{array}$ & $\begin{array}{c}-1.163^{* * *} \\
(0.262)\end{array}$ & $\begin{array}{c}-1.865 * * * \\
(0.208)\end{array}$ & $\begin{array}{c}-0.544 * * \\
(0.248)\end{array}$ \\
\hline Owner*(Age 65-69) & $\begin{array}{c}1.135 \\
(0.769)\end{array}$ & $\begin{array}{l}1.254^{* *} \\
(0.610)\end{array}$ & $\begin{array}{c}0.368 \\
(0.434)\end{array}$ & $\begin{array}{c}0.490 \\
(0.374)\end{array}$ & $\begin{array}{c}0.902 * * \\
(0.365)\end{array}$ & $\begin{array}{c}0.160 \\
(0.470)\end{array}$ & $\begin{array}{c}0.170 \\
(0.556)\end{array}$ & $\begin{array}{c}-0.312 \\
(0.824)\end{array}$ & $\begin{array}{c}-0.287 \\
(0.491)\end{array}$ & $\begin{array}{l}-0.397 \\
(0.403)\end{array}$ & $\begin{array}{l}-0.510 \\
(0.408)\end{array}$ & $\begin{array}{c}0.804 * \\
(0.411)\end{array}$ & $\begin{array}{c}-0.267 \\
(0.467)\end{array}$ \\
\hline Owner*(Age 70-74) & $\begin{array}{c}1.379 \\
(1.125)\end{array}$ & $\begin{array}{c}1.191^{* *} \\
(0.569)\end{array}$ & $\begin{array}{c}0.723 * \\
(0.422)\end{array}$ & $\begin{array}{c}0.149 \\
(0.548)\end{array}$ & $\begin{array}{c}-0.012 \\
(0.376)\end{array}$ & $\begin{array}{c}0.875^{*} \\
(0.448)\end{array}$ & $\begin{array}{c}0.396 \\
(0.489)\end{array}$ & $\begin{array}{c}0.347 \\
(0.926)\end{array}$ & $\begin{array}{l}-0.250 \\
(0.482)\end{array}$ & $\begin{array}{l}-0.193 \\
(0.387)\end{array}$ & $\begin{array}{l}-0.595 \\
(0.504)\end{array}$ & $\begin{array}{c}0.671^{*} \\
(0.372)\end{array}$ & $\begin{array}{c}2.108 * * * \\
(0.768)\end{array}$ \\
\hline Owner*(Age 75) & $\begin{array}{c}1.049 \\
(0.954)\end{array}$ & $\begin{array}{c}1.754 * * * \\
(0.501)\end{array}$ & $\begin{array}{c}0.865 * * \\
(0.354)\end{array}$ & $\begin{array}{c}1.813^{* * *} \\
(0.523)\end{array}$ & $\begin{array}{l}0.615^{*} \\
(0.334)\end{array}$ & $\begin{array}{c}0.853 * * \\
(0.433)\end{array}$ & $\begin{array}{c}0.060 \\
(0.627)\end{array}$ & & $\begin{array}{c}0.301 \\
(0.412)\end{array}$ & $\begin{array}{l}-0.045 \\
(0.399)\end{array}$ & $\begin{array}{l}-0.049 \\
(0.453)\end{array}$ & $\begin{array}{c}1.659 * * * \\
(0.434)\end{array}$ & $\begin{array}{c}0.430 \\
(0.316)\end{array}$ \\
\hline Log-Likelihood & -297.20 & -633.29 & -961.86 & -943.93 & -1349.62 & -1891.56 & -593.92 & -243.18 & -961.32 & -1244.83 & -859.04 & -1134.64 & -1282.01 \\
\hline Observations & 7025 & 7143 & 5910 & 6018 & 13795 & 14540 & 14064 & 7110 & 17436 & 10971 & 14960 & 16097 & 10783 \\
\hline
\end{tabular}

Notes: * significant at $10 \%$; ** significant at $5 \%$; ** significant at $1 \%$. Estimations include covariates as in Table 1 whose estimates are not reported as they are similar. 


\begin{tabular}{|c|c|c|c|c|c|c|}
\hline & \multicolumn{3}{|c|}{ Specification 1} & \multicolumn{3}{|c|}{ Specification 2} \\
\hline & All & North & South & All & North & South \\
\hline Age 65+ & $\begin{array}{c}-0.505^{* * *} \\
(0.080)\end{array}$ & $\begin{array}{c}-0.573^{* * *} \\
(0.093)\end{array}$ & $\begin{array}{c}-0.308 * \\
(0.164)\end{array}$ & & & \\
\hline Age 65-69 & & & & $\begin{array}{c}-0.359 * * * \\
(0.089)\end{array}$ & $\begin{array}{c}-0.425^{* * *} \\
(0.102)\end{array}$ & $\begin{array}{c}-0.141 \\
(0.183)\end{array}$ \\
\hline Age 70-74 & & & & $\begin{array}{c}-0.523^{* * *} \\
(0.109)\end{array}$ & $\begin{array}{c}-0.602 * * * \\
(0.126)\end{array}$ & $\begin{array}{c}-0.252 \\
(0.220)\end{array}$ \\
\hline Age $75+$ & & & & $\begin{array}{c}-0.607^{* * *} \\
(0.136)\end{array}$ & $\begin{array}{c}-0.656^{* * *} \\
(0.158)\end{array}$ & $\begin{array}{c}-0.426 \\
(0.276)\end{array}$ \\
\hline Owner & $\begin{array}{c}-1.615^{* * *} \\
(0.070)\end{array}$ & $\begin{array}{c}-1.587 * * * \\
(0.087)\end{array}$ & $\begin{array}{c}-1.676^{* * *} \\
(0.118)\end{array}$ & $\begin{array}{c}-1.623^{* * *} \\
(0.071)\end{array}$ & $\begin{array}{c}-1.602 * * * \\
(0.088)\end{array}$ & $\begin{array}{c}-1.677 * * * \\
(0.118)\end{array}$ \\
\hline Owner*(Age 65+) & $\begin{array}{c}0.458 * * * \\
(0.082)\end{array}$ & $\begin{array}{c}0.585^{* * *} \\
(0.097)\end{array}$ & $\begin{array}{c}0.192 \\
(0.156)\end{array}$ & & & \\
\hline Owner*(Age 65-69) & & & & $\begin{array}{c}0.234 * * \\
(0.113)\end{array}$ & $\begin{array}{c}0.355^{* * *} \\
(0.134)\end{array}$ & $\begin{array}{c}-0.052 \\
(0.212)\end{array}$ \\
\hline Owner*(Age 70-74) & & & & $\begin{array}{c}0.337 * * * \\
(0.121)\end{array}$ & $\begin{array}{c}0.468 * * * \\
(0.146)\end{array}$ & $\begin{array}{c}0.053 \\
(0.219)\end{array}$ \\
\hline Owner*(Age 75) & & & & $\begin{array}{c}0.726^{* * *} \\
(0.106)\end{array}$ & $\begin{array}{c}0.850^{* * *} \\
(0.123)\end{array}$ & $\begin{array}{c}0.544^{* *} \\
(0.220)\end{array}$ \\
\hline Outstanding Loan & $\begin{array}{c}0.325 * * * \\
(0.070)\end{array}$ & $\begin{array}{c}0.356 * * * \\
(0.080)\end{array}$ & $\begin{array}{c}-0.063 \\
(0.190)\end{array}$ & $\begin{array}{c}0.339 * * * \\
(0.070)\end{array}$ & $\begin{array}{c}0.377^{* * *} \\
(0.081)\end{array}$ & $\begin{array}{c}-0.057 \\
(0.190)\end{array}$ \\
\hline Retired & $\begin{array}{c}0.140 * * * \\
(0.053)\end{array}$ & $\begin{array}{c}0.173^{* * *} \\
(0.063)\end{array}$ & $\begin{array}{c}0.094 \\
(0.099)\end{array}$ & $\begin{array}{c}0.136 * * \\
(0.053)\end{array}$ & $\begin{array}{c}0.169 * * * \\
(0.063)\end{array}$ & $\begin{array}{c}0.096 \\
(0.100)\end{array}$ \\
\hline Spouse Retired & $\begin{array}{c}0.090 \\
(0.069)\end{array}$ & $\begin{array}{c}0.027 \\
(0.083)\end{array}$ & $\begin{array}{c}0.265^{* *} \\
(0.124)\end{array}$ & $\begin{array}{c}0.091 \\
(0.069)\end{array}$ & $\begin{array}{c}0.030 \\
(0.083)\end{array}$ & $\begin{array}{l}0.265^{* *} \\
(0.124)\end{array}$ \\
\hline Loss of Spouse & $\begin{array}{c}0.513^{* * *} \\
(0.096)\end{array}$ & $\begin{array}{c}0.639 * * * \\
(0.109)\end{array}$ & $\begin{array}{c}0.169 \\
(0.210)\end{array}$ & $\begin{array}{c}0.506^{* * *} \\
(0.097)\end{array}$ & $\begin{array}{c}0.632^{* * *} \\
(0.110)\end{array}$ & $\begin{array}{c}0.158 \\
(0.210)\end{array}$ \\
\hline Health Shock & $\begin{array}{c}0.029 \\
(0.049)\end{array}$ & $\begin{array}{c}-0.005 \\
(0.057)\end{array}$ & $\begin{array}{c}0.125 \\
(0.095)\end{array}$ & $\begin{array}{c}0.029 \\
(0.049)\end{array}$ & $\begin{array}{c}-0.005 \\
(0.057)\end{array}$ & $\begin{array}{c}0.125 \\
(0.095)\end{array}$ \\
\hline Health Shock - Spouse & $\begin{array}{c}-0.006 \\
(0.062)\end{array}$ & $\begin{array}{c}-0.017 \\
(0.074)\end{array}$ & $\begin{array}{c}0.006 \\
(0.111)\end{array}$ & $\begin{array}{c}-0.007 \\
(0.062)\end{array}$ & $\begin{array}{c}-0.018 \\
(0.074)\end{array}$ & $\begin{array}{c}0.007 \\
(0.111)\end{array}$ \\
\hline Presence of Children & $\begin{array}{c}0.072 \\
(0.095)\end{array}$ & $\begin{array}{c}-0.019 \\
(0.126)\end{array}$ & $\begin{array}{c}0.163 \\
(0.144)\end{array}$ & $\begin{array}{c}0.073 \\
(0.095)\end{array}$ & $\begin{array}{c}-0.019 \\
(0.127)\end{array}$ & $\begin{array}{c}0.159 \\
(0.145)\end{array}$ \\
\hline Couple & $\begin{array}{l}0.090 * \\
(0.051)\end{array}$ & $\begin{array}{c}0.031 \\
(0.058)\end{array}$ & $\begin{array}{l}0.209 * \\
(0.118)\end{array}$ & $\begin{array}{l}0.090 * \\
(0.051)\end{array}$ & $\begin{array}{c}0.032 \\
(0.058)\end{array}$ & $\begin{array}{c}0.208^{*} \\
(0.118)\end{array}$ \\
\hline Living in Appartment & $\begin{array}{c}-0.007 \\
(0.046)\end{array}$ & $\begin{array}{c}-0.089 \\
(0.056)\end{array}$ & $\begin{array}{c}0.220 * * \\
(0.088)\end{array}$ & $\begin{array}{c}-0.005 \\
(0.046)\end{array}$ & $\begin{array}{c}-0.088 \\
(0.056)\end{array}$ & $\begin{array}{c}0.221^{* *} \\
(0.088)\end{array}$ \\
\hline Housing Cost a Burden & $\begin{array}{c}0.196 * * * \\
(0.044)\end{array}$ & $\begin{array}{c}0.243^{* * *} \\
(0.050)\end{array}$ & $\begin{array}{c}0.116 \\
(0.091)\end{array}$ & $\begin{array}{c}0.193 * * * \\
(0.044)\end{array}$ & $\begin{array}{c}0.240^{* * *} \\
(0.050)\end{array}$ & $\begin{array}{c}0.111 \\
(0.091)\end{array}$ \\
\hline HH Income & $\begin{array}{c}0.006 \\
(0.004)\end{array}$ & $\begin{array}{c}0.007 \\
(0.004)\end{array}$ & $\begin{array}{c}0.018 \\
(0.029)\end{array}$ & $\begin{array}{l}0.007^{*} \\
(0.004)\end{array}$ & $\begin{array}{l}0.007^{*} \\
(0.004)\end{array}$ & $\begin{array}{c}0.018 \\
(0.029)\end{array}$ \\
\hline HH Wealth & $\begin{array}{c}0.032 * * \\
(0.013)\end{array}$ & $\begin{array}{c}0.029 * * \\
(0.014)\end{array}$ & $\begin{array}{c}0.161^{* *} \\
(0.071)\end{array}$ & $\begin{array}{c}0.032 * * \\
(0.013)\end{array}$ & $\begin{array}{l}0.029 * * \\
(0.014)\end{array}$ & $\begin{array}{l}0.159 * * \\
(0.072)\end{array}$ \\
\hline Cohort Effect & $\begin{array}{c}0.004 \\
(0.004)\end{array}$ & $\begin{array}{l}0.0001 \\
(0.004)\end{array}$ & $\begin{array}{l}0.016 * \\
(0.009)\end{array}$ & $\begin{array}{c}0.004 \\
(0.006)\end{array}$ & $\begin{array}{l}0.0001 \\
(0.007)\end{array}$ & $\begin{array}{c}0.019 \\
(0.012)\end{array}$ \\
\hline Constant & $\begin{array}{c}-2.750 * * * \\
(0.144)\end{array}$ & $\begin{array}{c}-2.613 * * * \\
(0.160)\end{array}$ & $\begin{array}{c}-4.224^{* * *} \\
(0.289)\end{array}$ & $\begin{array}{c}-2.735 * * * \\
(0.192)\end{array}$ & $\begin{array}{c}-2.606 * * * \\
(0.217)\end{array}$ & $\begin{array}{c}-4.291^{* * *} \\
(0.389)\end{array}$ \\
\hline Log-Likelihood & -12800.4 & -9110.77 & -3658.05 & -12790.89 & -9103.59 & -3654.83 \\
\hline Observations & 145852 & 83295 & 62557 & 145852 & 83295 & 62557 \\
\hline
\end{tabular}

Notes: * significant at 10\%; ** significant at 5\%; *** significant at 1\%. North includes: Austria, Belgium, Denmark, Finland, France, Germany, Ireland, and Netherlands. South includes: Greece, Italy, Spain, and Portugal. 
Table 4. Transitions of homeowners who moved (In 2-year intervals)

$\begin{array}{lccc}\text { All Age Groups } & \text { All Countries } & \text { North } & \text { South } \\ \text { To Ownership } & 69.41 & 66.89 & 75.26 \\ \text { To Renting } & 30.59 & 33.11 & 24.74\end{array}$

Age 50-59

To Ownership

$\begin{array}{lll}77.55 & 75.27 & 82.91\end{array}$

To Renting

22.45

24.73

17.09

Age 60-64

To Ownership

75.29

75.00

75.95

To Renting

24.71

25.00

24.05

Age 65-74

To Ownership

71.47

70.11

74.38

To Renting

28.53

29.89

25.62

Age $75^{+}$

To Ownership

49.26

43.65

64.00

To Renting

50.74

56.35

36.00

Source: ECHP (1994-2001). Own calculations.

Table 5. Change of Home Size for Owners who Move and Remain Owners

\begin{tabular}{lccc} 
& \multicolumn{3}{c}{ Home Size per Member of Household } \\
\cline { 2 - 4 } & All Countries & North & South \\
Less & 38.31 & 43.26 & 28.28 \\
More & 29.62 & 28.29 & 32.32 \\
Same & 32.03 & 28.45 & 39.39 \\
& \multicolumn{3}{c}{ Home Size } \\
\cline { 2 - 4 } & All Countries & North & South \\
& 36.97 & 43.43 & 23.91 \\
Less & 23.16 & 21.96 & 25.59 \\
More & 39.87 & 34.61 & 50.51 \\
Same & \multicolumn{3}{c}{}
\end{tabular}

Source: ECHP (1994-2001). Own calculations. 


\begin{tabular}{|c|c|c|c|c|c|c|c|c|c|c|c|c|c|c|}
\hline & \multicolumn{2}{|c|}{ Austria } & \multicolumn{2}{|c|}{ Belgium } & \multicolumn{2}{|c|}{ Denmark } & \multicolumn{2}{|c|}{ Finland } & \multicolumn{2}{|c|}{ France } & \multicolumn{2}{|c|}{ Germany } & \multicolumn{2}{|c|}{ Greece } \\
\hline \multirow[b]{2}{*}{ Age 65+ } & Own & Rent & Own & Rent & Own & Rent & Own & Rent & Own & Rent & Own & Rent & Own & Rent \\
\hline & $\begin{array}{l}-2.663 * \\
(1.389)\end{array}$ & $\begin{array}{c}-1.594^{* *} \\
(0.796)\end{array}$ & $\begin{array}{l}-1.206 \\
(0.838)\end{array}$ & $\begin{array}{c}-2.627 * * * \\
(0.504)\end{array}$ & $\begin{array}{c}-1.712^{* *} \\
(0.749)\end{array}$ & $\begin{array}{c}-1.173^{* * *} \\
(0.406)\end{array}$ & $\begin{array}{l}-0.236 \\
(0.527)\end{array}$ & $\begin{array}{c}-0.972 * * \\
(0.478)\end{array}$ & $\begin{array}{c}-1.859^{* * *} \\
(0.504)\end{array}$ & $\begin{array}{c}-1.424 * * * \\
(0.356)\end{array}$ & $\begin{array}{l}-0.748 \\
(0.555)\end{array}$ & $\begin{array}{c}-0.696 * * * \\
(0.191)\end{array}$ & $\begin{array}{c}-1.297 * * \\
(0.637)\end{array}$ & $\begin{array}{l}-0.750 \\
(0.608)\end{array}$ \\
\hline Owner & $\begin{array}{l}-1.163 \\
(0.828)\end{array}$ & $\begin{array}{l}-1.264 \\
(0.783)\end{array}$ & $\begin{array}{l}-0.500 \\
(0.538)\end{array}$ & $\begin{array}{c}-1.646^{* * *} \\
(0.611)\end{array}$ & $\begin{array}{c}0.355 \\
(0.572)\end{array}$ & $\begin{array}{l}-0.105 \\
(0.452)\end{array}$ & $\begin{array}{c}0.075 \\
(0.390)\end{array}$ & $\begin{array}{c}-2.010^{* * *} \\
(0.436)\end{array}$ & $\begin{array}{l}-0.641 * \\
(0.332)\end{array}$ & $\begin{array}{c}-2.047 * * * \\
(0.421)\end{array}$ & $\begin{array}{l}-0.187 \\
(0.438)\end{array}$ & $\begin{array}{c}-2.181 * * * \\
(0.484)\end{array}$ & $\begin{array}{l}-0.134 \\
(0.396)\end{array}$ & $\begin{array}{l}-0.923^{*} \\
(0.560)\end{array}$ \\
\hline Owner*(Age 65+) & $\begin{array}{l}2.625^{* *} \\
(1.214) \\
\end{array}$ & $\begin{array}{r}0.159 \\
(0.943) \\
\end{array}$ & $\begin{array}{c}1.196 \\
(0.763) \\
\end{array}$ & $\begin{array}{c}0.830 \\
(0.670) \\
\end{array}$ & $\begin{array}{c}0.802 \\
(0.715) \\
\end{array}$ & $\begin{array}{c}0.104 \\
(0.416) \\
\end{array}$ & $\begin{array}{r}0.084 \\
(0.512) \\
\end{array}$ & $\begin{array}{r}0.529 \\
(0.490) \\
\end{array}$ & $\begin{array}{r}0.560 \\
(0.437) \\
\end{array}$ & $\begin{array}{r}0.664 \\
(0.462) \\
\end{array}$ & $\begin{array}{r}0.834 \\
(0.575) \\
\end{array}$ & $\begin{array}{c}1.514 * * * \\
(0.479) \\
\end{array}$ & $\begin{array}{r}0.525 \\
(0.623) \\
\end{array}$ & $\begin{array}{c}0.127 \\
(0.604) \\
\end{array}$ \\
\hline & & & & ly & Neth & lands & Por & & $\mathrm{Sp}$ & & & & & \\
\hline & Own & Rent & Own & Rent & Own & Rent & Own & Rent & Own & Rent & Own & Rent & & \\
\hline Age 65+ & $\begin{array}{c}0.090 \\
(1.626)\end{array}$ & $\begin{array}{c}1.183 \\
(1.469)\end{array}$ & $\begin{array}{c}-1.897 * * * \\
(0.641)\end{array}$ & $\begin{array}{c}-1.160 * * * \\
(0.389)\end{array}$ & $\begin{array}{c}-1.940^{* * *} \\
(0.528)\end{array}$ & $\begin{array}{c}-0.879 * * * \\
(0.288)\end{array}$ & $\begin{array}{l}-0.534 \\
(0.394)\end{array}$ & $\begin{array}{l}-0.755 \\
(0.464)\end{array}$ & $\begin{array}{c}-1.391 * * * \\
(0.418)\end{array}$ & $\begin{array}{c}-2.893 * * * \\
(0.844)\end{array}$ & $\begin{array}{c}-2.723 * * \\
(1.234)\end{array}$ & $\begin{array}{c}-2.117 * * * \\
(0.546)\end{array}$ & & \\
\hline Owner & $\begin{array}{l}-0.123 \\
(1.259)\end{array}$ & $\begin{array}{c}0.145 \\
(1.131)\end{array}$ & $\begin{array}{c}-0.603 * * \\
(0.283)\end{array}$ & $\begin{array}{c}-3.088^{* * *} \\
(0.471)\end{array}$ & $\begin{array}{c}1.559 * * * \\
(0.425)\end{array}$ & $\begin{array}{c}-0.871^{* *} \\
(0.427)\end{array}$ & $\begin{array}{c}-0.917 * * * \\
(0.342)\end{array}$ & $\begin{array}{c}-2.154 * * * \\
(0.522)\end{array}$ & $\begin{array}{c}-0.821 * * * \\
(0.282)\end{array}$ & $\begin{array}{c}-1.822 * * * \\
(0.367)\end{array}$ & $\begin{array}{c}2.576^{* * *} \\
(0.651)\end{array}$ & $\begin{array}{c}-1.353 * * * \\
(0.462)\end{array}$ & & \\
\hline Owner*(Age 65+) & $\begin{array}{c}0.423 \\
(1.771) \\
\end{array}$ & $\begin{array}{l}-1.315 \\
(1.396) \\
\end{array}$ & $\begin{array}{r}0.201 \\
(0.520) \\
\end{array}$ & $\begin{array}{c}1.388^{* * *} \\
(0.539)\end{array}$ & & $\begin{array}{r}0.353 \\
(0.387) \\
\end{array}$ & $\begin{array}{l}-0.311 \\
(0.447) \\
\end{array}$ & $\begin{array}{c}0.444 \\
(0.654)\end{array}$ & $\begin{array}{l}0.627^{*} \\
(0.371) \\
\end{array}$ & $\begin{array}{l}1.153^{*} \\
(0.593)\end{array}$ & $\begin{array}{r}0.917 \\
(1.220) \\
\end{array}$ & $\begin{array}{r}0.807 \\
(0.506) \\
\end{array}$ & & \\
\hline
\end{tabular}

Notes: * significant at $10 \%$;* significant at $5 \%$; *** significant at $1 \%$. The table presents only the coefficients for the age dummy, the ownership dummy and their interaction. All other

estimates are shown in Table A1. The model is estimated for each country separately including regional dummies. For each country the column named Own refers to the transition towards ownership and the column named Rent refers to the transition towards renting. 


\begin{tabular}{|c|c|c|c|c|c|}
\hline & Denmark & Finland & France & $\overline{\text { Germany }}$ & Greece \\
\hline Age 65-69 & & $\begin{array}{c}-0.872 * \\
(0.478)\end{array}$ & $\begin{array}{c}-1.517^{* * *} \\
(0.420)\end{array}$ & $\begin{array}{c}-0.741^{* * *} \\
(0.186)\end{array}$ & $\begin{array}{c}-1.317^{* *} \\
(0.617)\end{array}$ \\
\hline Age 70-74 & $\begin{array}{c}-1.201 * * * \\
(0.399)\end{array}$ & $\begin{array}{c}0.224 \\
(0.711)\end{array}$ & $\begin{array}{c}-1.725^{* * *} \\
(0.365)\end{array}$ & $\begin{array}{c}-1.590 * * * \\
(0.268)\end{array}$ & $\begin{array}{l}-1.456^{*} \\
(0.812)\end{array}$ \\
\hline Age $75+$ & $\begin{array}{c}-2.258^{* * *} \\
(0.584)\end{array}$ & $\begin{array}{l}-1.540 * \\
(0.885)\end{array}$ & $\begin{array}{c}-3.185^{* * *} \\
(0.558)\end{array}$ & $\begin{array}{c}-2.916^{* * *} \\
(0.466)\end{array}$ & $\begin{array}{c}-3.530 * * * \\
(1.129)\end{array}$ \\
\hline Owner & $\begin{array}{c}-0.097 \\
(0.459)\end{array}$ & $\begin{array}{c}-2.051^{* * *} \\
(0.450)\end{array}$ & $\begin{array}{c}-2.106^{* * *} \\
(0.418)\end{array}$ & $\begin{array}{c}-2.226 * * * \\
(0.491)\end{array}$ & $\begin{array}{c}-1.052 * \\
(0.556)\end{array}$ \\
\hline Owner * Age 65-69 & & $\begin{array}{c}0.225 \\
(0.696)\end{array}$ & $\begin{array}{c}0.502 \\
(0.683)\end{array}$ & $\begin{array}{c}0.980 \\
(0.664)\end{array}$ & $\begin{array}{c}0.344 \\
(0.829)\end{array}$ \\
\hline Owner * Age 70-74 & $\begin{array}{c}-0.132 \\
(0.493)\end{array}$ & $\begin{array}{c}-1.034 \\
(0.802)\end{array}$ & $\begin{array}{c}0.128 \\
(0.653)\end{array}$ & $\begin{array}{c}1.555^{* * *} \\
(0.587)\end{array}$ & $\begin{array}{c}-0.087 \\
(0.826)\end{array}$ \\
\hline Owner * Age 75+ & $\begin{array}{c}0.224 \\
(0.465) \\
\end{array}$ & $\begin{array}{c}1.668 * * \\
(0.740)\end{array}$ & $\begin{array}{c}1.223^{* *} \\
(0.509)\end{array}$ & $\begin{array}{c}2.194^{* * *} \\
(0.555)\end{array}$ & $\begin{array}{c}0.297 \\
(0.823) \\
\end{array}$ \\
\hline & Italy & Netherlands & Portugal & Spain & UK \\
\hline Age 65-69 & $\begin{array}{c}-1.174 * * \\
(0.496)\end{array}$ & $\begin{array}{c}-1.283^{* * * *} \\
(0.292)\end{array}$ & $\begin{array}{c}-1.220^{* * *} \\
(0.467)\end{array}$ & $\begin{array}{c}-2.827 * * * \\
(0.868)\end{array}$ & $\begin{array}{c}-0.999 * * \\
(0.426)\end{array}$ \\
\hline Age $70-74$ & $\begin{array}{c}-1.337 * * * \\
(0.463)\end{array}$ & $\begin{array}{c}-1.466^{* * *} \\
(0.315)\end{array}$ & $\begin{array}{c}-1.895^{* * *} \\
(0.560)\end{array}$ & $\begin{array}{c}-2.822 * * * \\
(0.648)\end{array}$ & $\begin{array}{c}-3.436 * * * \\
(0.836)\end{array}$ \\
\hline Age $75+$ & $\begin{array}{c}-2.151^{* * *} \\
(0.757)\end{array}$ & $\begin{array}{c}-3.449 * * * \\
(0.560)\end{array}$ & $\begin{array}{c}-4.207^{* * *} \\
(1.029)\end{array}$ & $\begin{array}{c}-7.521^{* * *} \\
(1.530)\end{array}$ & $\begin{array}{c}-3.841 * * * \\
(0.754)\end{array}$ \\
\hline Owner & $\begin{array}{c}-3.095^{* * *} \\
(0.472)\end{array}$ & $\begin{array}{c}-0.901^{* *} \\
(0.443)\end{array}$ & $\begin{array}{c}-2.149 * * * \\
(0.523)\end{array}$ & $\begin{array}{c}-1.815^{* * *} \\
(0.362)\end{array}$ & $\begin{array}{c}-1.427^{* * *} \\
(0.461)\end{array}$ \\
\hline Owner * Age 65-69 & $\begin{array}{c}1.116 \\
(0.881)\end{array}$ & $\begin{array}{c}0.322 \\
(0.537)\end{array}$ & $\begin{array}{c}0.430 \\
(0.793)\end{array}$ & $\begin{array}{c}0.177 \\
(1.067)\end{array}$ & $\begin{array}{c}-0.182 \\
(0.768)\end{array}$ \\
\hline Owner * Age 70-74 & $\begin{array}{c}1.194 \\
(0.732)\end{array}$ & $\begin{array}{c}-0.263 \\
(0.470)\end{array}$ & $\begin{array}{c}0.021 \\
(0.853)\end{array}$ & $\begin{array}{c}0.160 \\
(0.708)\end{array}$ & $\begin{array}{c}1.470 \\
(0.930)\end{array}$ \\
\hline Owner * Age $75+$ & $\begin{array}{c}1.654^{* * *} \\
(0.621) \\
\end{array}$ & $\begin{array}{c}0.777 \\
(0.547) \\
\end{array}$ & $\begin{array}{c}1.002 \\
(0.844) \\
\end{array}$ & $\begin{array}{c}2.893 * * \\
(1.150) \\
\end{array}$ & $\begin{array}{l}1.034 * \\
(0.531)\end{array}$ \\
\hline
\end{tabular}

Notes: * significant at $10 \%$; ** significant at $5 \%$; *** significant at $1 \%$. The table presents only the coefficients for the transition to renting for specification 2 with different age dummies. Due to small number of transitions to ownership for old age groups, specification 2 could not be estimated for the exits to ownership. 


\begin{tabular}{|c|c|c|c|c|c|c|}
\hline & & & \multicolumn{2}{|c|}{ ALL COUNTRIES } & & \\
\hline & \multicolumn{2}{|c|}{ All HH } & \multicolumn{2}{|c|}{ Couple HH } & \multicolumn{2}{|c|}{ Single HH } \\
\hline & \multicolumn{2}{|c|}{ Exit to } & \multicolumn{2}{|c|}{ Exit to } & \multicolumn{2}{|c|}{ Exit to } \\
\hline & Ownership & Rent & Ownership & Rent & Ownership & Rent \\
\hline Age 65+ & $\begin{array}{c}-1.487 * * * \\
(0.165)\end{array}$ & $\begin{array}{c}-1.135^{* * *} \\
(0.109)\end{array}$ & $\begin{array}{c}-1.515^{* * *} \\
(0.179)\end{array}$ & $\begin{array}{c}-1.018^{* * *} \\
(0.139)\end{array}$ & $\begin{array}{c}-0.960 * * \\
(0.391)\end{array}$ & $\begin{array}{c}-1.403^{* * *} \\
(0.173)\end{array}$ \\
\hline Owner & $\begin{array}{c}-0.257^{* *} \\
(0.113)\end{array}$ & $\begin{array}{c}-1.745^{* * *} \\
(0.129)\end{array}$ & $\begin{array}{c}-0.319 * * * \\
(0.118)\end{array}$ & $\begin{array}{c}-1.836 * * * \\
(0.153)\end{array}$ & $\begin{array}{c}0.138 \\
(0.342)\end{array}$ & $\begin{array}{c}-1.377 * * * \\
(0.248)\end{array}$ \\
\hline \multirow[t]{5}{*}{ Owner*(Age 65+) } & $\begin{array}{c}0.636^{* * *} \\
(0.144) \\
\end{array}$ & $\begin{array}{c}0.556^{* * * *} \\
(0.134) \\
\end{array}$ & $\begin{array}{c}0.475^{* * *} \\
(0.157) \\
\end{array}$ & $\begin{array}{c}0.385^{* *} \\
(0.164) \\
\end{array}$ & $\begin{array}{c}0.804 * * \\
(0.372) \\
\end{array}$ & $\begin{array}{c}0.528 * * \\
(0.250) \\
\end{array}$ \\
\hline & & & \multicolumn{2}{|c|}{ NORTH } & & \\
\hline & \multicolumn{2}{|c|}{ All HH } & \multicolumn{2}{|c|}{ Couple HH } & \multicolumn{2}{|c|}{ Single HH } \\
\hline & \multicolumn{2}{|c|}{ Exit to } & \multicolumn{2}{|c|}{ Exit to } & \multicolumn{2}{|c|}{ Exit to } \\
\hline & Ownership & Rent & Ownership & Rent & Ownership & Rent \\
\hline Age 65+ & $\begin{array}{c}-1.918 * * * \\
(0.234)\end{array}$ & $\begin{array}{c}-1.132^{* * *} \\
(0.121)\end{array}$ & $\begin{array}{c}-2.013^{* * *} \\
(0.269)\end{array}$ & $\begin{array}{c}-0.934^{* * *} \\
(0.156)\end{array}$ & $\begin{array}{c}-1.211^{* * *} \\
(0.465)\end{array}$ & $\begin{array}{c}-1.519 * * * \\
(0.192)\end{array}$ \\
\hline Owner & $\begin{array}{c}0.107 \\
(0.149)\end{array}$ & $\begin{array}{c}-1.559 * * * \\
(0.156)\end{array}$ & $\begin{array}{c}0.036 \\
(0.161)\end{array}$ & $\begin{array}{c}-1.720 * * * \\
(0.193)\end{array}$ & $\begin{array}{c}0.324 \\
(0.390)\end{array}$ & $\begin{array}{c}-1.156 * * * \\
(0.268)\end{array}$ \\
\hline \multirow[t]{5}{*}{ Owner*(Age 65+) } & $\begin{array}{c}1.131^{* * *} \\
(0.205) \\
\end{array}$ & $\begin{array}{c}0.575^{* * *} \\
(0.155) \\
\end{array}$ & $\begin{array}{c}1.012 * * * \\
(0.238) \\
\end{array}$ & $\begin{array}{l}0.451 * * \\
(0.194) \\
\end{array}$ & $\begin{array}{c}1.176^{* * * *} \\
(0.436) \\
\end{array}$ & $\begin{array}{l}0.491 * \\
(0.271) \\
\end{array}$ \\
\hline & & & \multicolumn{2}{|c|}{ SOUTH } & & \\
\hline & \multicolumn{2}{|c|}{ All HH } & \multicolumn{2}{|c|}{ Couple HH } & \multicolumn{2}{|c|}{ Single HH } \\
\hline & \multicolumn{2}{|c|}{ Exit to } & \multicolumn{2}{|c|}{ Exit to } & \multicolumn{2}{|c|}{ Exit to } \\
\hline & Ownership & Rent & Ownership & Rent & Ownership & Rent \\
\hline Age 65+ & $\begin{array}{c}-1.086 * * * \\
(0.241)\end{array}$ & $\begin{array}{c}-1.107 * * * \\
(0.253)\end{array}$ & $\begin{array}{c}-1.152^{* * *} \\
(0.255)\end{array}$ & $\begin{array}{c}-1.299 * * * \\
(0.311)\end{array}$ & $\begin{array}{c}-0.734 \\
(0.770)\end{array}$ & $\begin{array}{l}-0.825 * \\
(0.465)\end{array}$ \\
\hline Owner & $\begin{array}{c}-0.735^{* * *} \\
(0.155)\end{array}$ & $\begin{array}{c}-2.094^{* * *} \\
(0.216)\end{array}$ & $\begin{array}{c}-0.752 * * * \\
(0.161)\end{array}$ & $\begin{array}{c}-2.093^{* * *} \\
(0.234)\end{array}$ & $\begin{array}{l}-0.390 \\
(0.608)\end{array}$ & $\begin{array}{c}-1.983^{* * * *} \\
(0.598)\end{array}$ \\
\hline Owner*(Age 65+) & $\begin{array}{c}0.080 \\
(0.214) \\
\end{array}$ & $\begin{array}{c}0.481 * \\
(0.271)\end{array}$ & $\begin{array}{c}0.032 \\
(0.226) \\
\end{array}$ & $\begin{array}{c}0.353 \\
(0.309) \\
\end{array}$ & $\begin{array}{c}0.002 \\
(0.730) \\
\end{array}$ & $\begin{array}{c}0.638 \\
(0.654) \\
\end{array}$ \\
\hline
\end{tabular}

Notes: * significant at 10\%; ** significant at 5\%; *** significant at 1\%. North includes: Austria, Belgium, Denmark, Finland, France, Germany, Ireland, and Netherlands. South includes: Greece, Italy, Spain, and Portugal. Estimates for the other variables are not presented but are available from the author upon request. 


\section{Appendix}

\begin{tabular}{|c|c|c|c|c|c|c|c|c|c|c|c|c|c|c|}
\hline \multirow[b]{3}{*}{ Outstanding Loan } & \multicolumn{2}{|c|}{ Austria } & \multicolumn{2}{|c|}{ Belgium } & \multicolumn{2}{|c|}{ Denmark } & \multicolumn{2}{|c|}{ Finland } & \multicolumn{2}{|c|}{ France } & \multicolumn{2}{|c|}{ Germany } & \multicolumn{2}{|c|}{ Greece } \\
\hline & Own & Rent & Own & Rent & Own & Rent & Own & Rent & Own & Rent & Own & Rent & Own & Rent \\
\hline & $\begin{array}{c}0.079 \\
(0.680)\end{array}$ & $\begin{array}{l}-0.089 \\
(0.928)\end{array}$ & $\begin{array}{c}-1.197^{* *} \\
(0.568)\end{array}$ & $\begin{array}{l}-0.426 \\
(0.765)\end{array}$ & $\begin{array}{c}0.244 \\
(0.353)\end{array}$ & $\begin{array}{l}-0.406 \\
(0.328)\end{array}$ & $\begin{array}{l}-0.387^{*} \\
(0.227)\end{array}$ & $\begin{array}{c}0.128 \\
(0.398)\end{array}$ & $\begin{array}{l}-0.451 \\
(0.289)\end{array}$ & $\begin{array}{l}-0.588 \\
(0.486)\end{array}$ & $\begin{array}{l}-0.315 \\
(0.421)\end{array}$ & $\begin{array}{c}0.082 \\
(0.425)\end{array}$ & $\begin{array}{l}-0.605 \\
(0.556)\end{array}$ & $\begin{array}{l}-0.836 \\
(1.029)\end{array}$ \\
\hline Retired & $\begin{array}{l}-0.596 \\
(0.554)\end{array}$ & $\begin{array}{l}-0.055 \\
(0.504)\end{array}$ & $\begin{array}{l}-0.625 \\
(0.455)\end{array}$ & $\begin{array}{l}-0.796^{*} \\
(0.420)\end{array}$ & $\begin{array}{l}-0.184 \\
(0.317)\end{array}$ & $\begin{array}{l}-0.012 \\
(0.283)\end{array}$ & $\begin{array}{l}-0.066 \\
(0.280)\end{array}$ & $\begin{array}{l}-0.160 \\
(0.339)\end{array}$ & $\begin{array}{c}0.121 \\
(0.221)\end{array}$ & $\begin{array}{c}-0.739 * * \\
(0.324)\end{array}$ & $\begin{array}{c}0.074 \\
(0.283)\end{array}$ & $\begin{array}{l}-0.184 \\
(0.135)\end{array}$ & $\begin{array}{l}-0.376 \\
(0.330)\end{array}$ & $\begin{array}{c}-0.926^{* *} \\
(0.457)\end{array}$ \\
\hline Spouse Retired & $\begin{array}{l}-1.435 \\
(1.051)\end{array}$ & & $\begin{array}{c}-1.158^{* *} \\
(0.560)\end{array}$ & $\begin{array}{l}-0.032 \\
(0.439)\end{array}$ & $\begin{array}{c}0.091 \\
(0.348)\end{array}$ & $\begin{array}{c}0.302 \\
(0.323)\end{array}$ & $\begin{array}{l}-0.115 \\
(0.318)\end{array}$ & $\begin{array}{l}-0.224 \\
(0.385)\end{array}$ & $\begin{array}{c}0.070 \\
(0.260)\end{array}$ & $\begin{array}{l}-0.966^{*} \\
(0.534)\end{array}$ & $\begin{array}{c}-1.199 * * * \\
(0.463)\end{array}$ & $\begin{array}{l}-0.163 \\
(0.165)\end{array}$ & $\begin{array}{l}-1.215^{*} \\
(0.725)\end{array}$ & $\begin{array}{l}-0.313 \\
(0.548)\end{array}$ \\
\hline Loss of Spouse & $\begin{array}{l}-0.183 \\
(1.196)\end{array}$ & $\begin{array}{c}-0.155 \\
(1.042)\end{array}$ & $\begin{array}{l}-0.846 \\
(1.019)\end{array}$ & $\begin{array}{c}0.720 \\
(0.498)\end{array}$ & $\begin{array}{c}0.384 \\
(0.369)\end{array}$ & $\begin{array}{c}0.104 \\
(0.425)\end{array}$ & $\begin{array}{c}0.927^{* *} \\
(0.381)\end{array}$ & $\begin{array}{l}0.949 * * \\
(0.430)\end{array}$ & $\begin{array}{l}-0.903 \\
(0.739)\end{array}$ & $\begin{array}{c}0.927 * * * \\
(0.323)\end{array}$ & $\begin{array}{l}-1.245 \\
(1.039)\end{array}$ & $\begin{array}{c}0.066 \\
(0.256)\end{array}$ & & \\
\hline Couple & $\begin{array}{l}1.950^{*} \\
(1.069)\end{array}$ & $\begin{array}{l}-0.362 \\
(0.439)\end{array}$ & $\begin{array}{l}1.039^{* *} \\
(0.499)\end{array}$ & $\begin{array}{c}0.195 \\
(0.307)\end{array}$ & $\begin{array}{l}0.760^{* *} \\
(0.344)\end{array}$ & $\begin{array}{c}0.274 \\
(0.293)\end{array}$ & $\begin{array}{l}-0.028 \\
(0.273)\end{array}$ & $\begin{array}{l}0.656^{*} \\
(0.371)\end{array}$ & $\begin{array}{c}0.882^{* * *} \\
(0.295)\end{array}$ & $\begin{array}{c}0.100 \\
(0.227)\end{array}$ & $\begin{array}{c}0.504 \\
(0.365)\end{array}$ & $\begin{array}{l}-0.104 \\
(0.166)\end{array}$ & $\begin{array}{l}1.391^{* *} \\
(0.673)\end{array}$ & $\begin{array}{l}0.823^{*} \\
(0.465)\end{array}$ \\
\hline Presence of Children & $\begin{array}{c}0.242 \\
(0.631)\end{array}$ & $\begin{array}{l}-0.893 \\
(1.056)\end{array}$ & $\begin{array}{c}0.303 \\
(0.392)\end{array}$ & $\begin{array}{c}0.024 \\
(0.378)\end{array}$ & $\begin{array}{l}-0.442 \\
(0.529)\end{array}$ & $\begin{array}{l}-0.907 \\
(1.023)\end{array}$ & $\begin{array}{c}-0.713^{* *} \\
(0.353)\end{array}$ & $\begin{array}{l}-0.142 \\
(0.427)\end{array}$ & $\begin{array}{l}-0.501 \\
(0.354)\end{array}$ & $\begin{array}{l}-0.395 \\
(0.332)\end{array}$ & $\begin{array}{c}0.159 \\
(0.350)\end{array}$ & $\begin{array}{c}0.094 \\
(0.217)\end{array}$ & $\begin{array}{c}0.255 \\
(0.342)\end{array}$ & $\begin{array}{c}0.072 \\
(0.423)\end{array}$ \\
\hline Health Shock & $\begin{array}{c}0.479 \\
(0.484)\end{array}$ & $\begin{array}{c}-0.261 \\
(0.457)\end{array}$ & $\begin{array}{c}0.212 \\
(0.364)\end{array}$ & $\begin{array}{c}0.143 \\
(0.276)\end{array}$ & $\begin{array}{c}0.086 \\
(0.261)\end{array}$ & $\begin{array}{c}0.207 \\
(0.225)\end{array}$ & $\begin{array}{l}-0.522^{*} \\
(0.284)\end{array}$ & $\begin{array}{c}0.309 \\
(0.289)\end{array}$ & $\begin{array}{l}-0.161 \\
(0.240)\end{array}$ & $\begin{array}{l}-0.217 \\
(0.238)\end{array}$ & $\begin{array}{l}-0.168 \\
(0.288)\end{array}$ & $\begin{array}{l}-0.300^{*} \\
(0.158)\end{array}$ & $\begin{array}{c}0.443 \\
(0.337)\end{array}$ & $\begin{array}{c}0.493 \\
(0.399)\end{array}$ \\
\hline Health Shock-Spouse & $\begin{array}{l}1.120^{* *} \\
(0.542)\end{array}$ & $\begin{array}{c}0.046 \\
(0.772)\end{array}$ & $\begin{array}{c}0.168 \\
(0.416)\end{array}$ & $\begin{array}{c}0.028 \\
(0.448)\end{array}$ & $\begin{array}{l}-0.127 \\
(0.338)\end{array}$ & $\begin{array}{c}0.396 \\
(0.313)\end{array}$ & $\begin{array}{l}-0.270 \\
(0.324)\end{array}$ & $\begin{array}{l}-1.552 * \\
(0.843)\end{array}$ & $\begin{array}{c}0.255 \\
(0.240)\end{array}$ & $\begin{array}{l}-0.055 \\
(0.340)\end{array}$ & $\begin{array}{c}0.204 \\
(0.315)\end{array}$ & $\begin{array}{l}-0.055 \\
(0.201)\end{array}$ & $\begin{array}{c}0.675 * * \\
(0.329)\end{array}$ & $\begin{array}{l}-0.526 \\
(0.577)\end{array}$ \\
\hline Living in Appartment & $\begin{array}{l}1.029 * * \\
(0.429)\end{array}$ & $\begin{array}{c}0.325 \\
(0.391)\end{array}$ & $\begin{array}{l}-0.187 \\
(0.449)\end{array}$ & $\begin{array}{c}0.254 \\
(0.280)\end{array}$ & $\begin{array}{l}-0.689^{*} \\
(0.413)\end{array}$ & $\begin{array}{l}0.433^{* *} \\
(0.212)\end{array}$ & $\begin{array}{l}-0.061 \\
(0.230)\end{array}$ & $\begin{array}{l}-0.080 \\
(0.264)\end{array}$ & $\begin{array}{c}0.391 \\
(0.255)\end{array}$ & $\begin{array}{l}-0.213 \\
(0.195)\end{array}$ & $\begin{array}{l}-0.585^{*} \\
(0.332)\end{array}$ & $\begin{array}{l}-0.095 \\
(0.136)\end{array}$ & $\begin{array}{c}0.274 \\
(0.300)\end{array}$ & $\begin{array}{l}-0.313 \\
(0.360)\end{array}$ \\
\hline Housing Costs a Burden & $\begin{array}{c}0.115 \\
(0.512)\end{array}$ & $\begin{array}{c}1.286 * * * \\
(0.430)\end{array}$ & $\begin{array}{c}0.701^{* *} \\
(0.343)\end{array}$ & $\begin{array}{c}0.877 * * * \\
(0.272)\end{array}$ & $\begin{array}{c}1.063 * * * \\
(0.262)\end{array}$ & $\begin{array}{c}1.415^{* * *} \\
(0.212)\end{array}$ & $\begin{array}{c}1.455^{* * *} \\
(0.197)\end{array}$ & $\begin{array}{c}1.502 * * * \\
(0.250)\end{array}$ & $\begin{array}{c}1.096^{* * *} \\
(0.213)\end{array}$ & $\begin{array}{c}1.415^{* * *} \\
(0.178)\end{array}$ & $\begin{array}{c}1.778 * * * \\
(0.273)\end{array}$ & $\begin{array}{c}1.586^{* * * *} \\
(0.133)\end{array}$ & $\begin{array}{c}2.328 * * * \\
(0.348)\end{array}$ & $\begin{array}{c}2.210^{* * *} \\
(0.432)\end{array}$ \\
\hline HH Income & $\begin{array}{l}-0.002 \\
(0.082)\end{array}$ & $\begin{array}{l}-0.223 \\
(0.183)\end{array}$ & $\begin{array}{c}0.077 \\
(0.061)\end{array}$ & $\begin{array}{c}-0.327^{* *} \\
(0.142)\end{array}$ & $\begin{array}{c}0.013 \\
(0.049)\end{array}$ & $\begin{array}{c}-0.340^{* *} \\
(0.133)\end{array}$ & $\begin{array}{c}0.145^{* *} \\
(0.072)\end{array}$ & $\begin{array}{l}-0.223 \\
(0.139)\end{array}$ & $\begin{array}{c}0.190^{* * * *} \\
(0.043)\end{array}$ & $\begin{array}{c}0.036 \\
(0.074)\end{array}$ & $\begin{array}{c}0.034 \\
(0.077)\end{array}$ & $\begin{array}{c}-0.132^{* *} \\
(0.062)\end{array}$ & $\begin{array}{l}-0.042 \\
(0.173)\end{array}$ & $\begin{array}{l}-0.119 \\
(0.133)\end{array}$ \\
\hline HH Wealth & $\begin{array}{l}-0.538 \\
(0.786)\end{array}$ & $\begin{array}{l}0.419^{*} \\
(0.243)\end{array}$ & $\begin{array}{l}-0.056 \\
(0.062)\end{array}$ & $\begin{array}{c}0.207 \\
(0.282)\end{array}$ & $\begin{array}{l}-0.292 \\
(0.243)\end{array}$ & $\begin{array}{l}-0.212 \\
(0.964)\end{array}$ & $\begin{array}{l}-0.090 \\
(0.083)\end{array}$ & $\begin{array}{c}0.339 * * * \\
(0.101)\end{array}$ & $\begin{array}{l}0.341^{* *} \\
(0.171)\end{array}$ & $\begin{array}{l}-0.657 \\
(0.523)\end{array}$ & $\begin{array}{l}0.193^{*} \\
(0.115)\end{array}$ & $\begin{array}{l}-0.048 \\
(0.247)\end{array}$ & $\begin{array}{c}0.037 \\
(0.237)\end{array}$ & $\begin{array}{l}-0.612 \\
(1.072)\end{array}$ \\
\hline Cohort Effect & $\begin{array}{l}-0.018 \\
(0.044)\end{array}$ & $\begin{array}{l}-0.040 \\
(0.036)\end{array}$ & $\begin{array}{c}0.028 \\
(0.028)\end{array}$ & $\begin{array}{c}-0.071 * * * \\
(0.019)\end{array}$ & $\begin{array}{c}-0.052 * * * \\
(0.019)\end{array}$ & $\begin{array}{c}-0.044 * * * \\
(0.015)\end{array}$ & $\begin{array}{l}-0.005 \\
(0.017)\end{array}$ & $\begin{array}{l}-0.037 \\
(0.025)\end{array}$ & $\begin{array}{l}-0.032^{*} \\
(0.018)\end{array}$ & $\begin{array}{c}-0.040^{* * * *} \\
(0.014)\end{array}$ & $\begin{array}{c}0.024 \\
(0.026)\end{array}$ & $\begin{array}{l}-0.018^{*} \\
(0.010)\end{array}$ & $\begin{array}{l}-0.020 \\
(0.027)\end{array}$ & $\begin{array}{l}-0.020 \\
(0.027)\end{array}$ \\
\hline Duration 3-6 & $\begin{array}{l}-0.572 \\
(0.478)\end{array}$ & $\begin{array}{l}-0.411 \\
(0.457)\end{array}$ & $\begin{array}{c}0.768^{* *} \\
(0.390)\end{array}$ & $\begin{array}{l}0.482 * \\
(0.269)\end{array}$ & $\begin{array}{c}0.037 \\
(0.247)\end{array}$ & $\begin{array}{c}0.857 * * * \\
(0.233)\end{array}$ & $\begin{array}{l}-0.071 \\
(0.247)\end{array}$ & $\begin{array}{c}0.246 \\
(0.294)\end{array}$ & $\begin{array}{c}0.447^{* *} \\
(0.211)\end{array}$ & $\begin{array}{c}0.137 \\
(0.217)\end{array}$ & $\begin{array}{c}0.018 \\
(0.268)\end{array}$ & $\begin{array}{l}0.293^{* *} \\
(0.144)\end{array}$ & $\begin{array}{l}-0.526 \\
(0.372)\end{array}$ & $\begin{array}{c}0.317 \\
(0.333)\end{array}$ \\
\hline Duration 6-9 & $\begin{array}{l}-1.248 \\
(1.029)\end{array}$ & $\begin{array}{l}-0.149 \\
(0.399)\end{array}$ & $\begin{array}{c}0.579 \\
(0.492)\end{array}$ & $\begin{array}{c}0.433 \\
(0.321)\end{array}$ & $\begin{array}{l}-0.322 \\
(0.337)\end{array}$ & $\begin{array}{c}0.184 \\
(0.332)\end{array}$ & $\begin{array}{l}-0.219 \\
(0.325)\end{array}$ & $\begin{array}{c}0.385 \\
(0.333)\end{array}$ & $\begin{array}{l}-0.159 \\
(0.308)\end{array}$ & $\begin{array}{c}0.220 \\
(0.249)\end{array}$ & $\begin{array}{l}-0.348 \\
(0.380)\end{array}$ & $\begin{array}{c}0.574 * * * \\
(0.156)\end{array}$ & $\begin{array}{l}-0.458 \\
(0.451)\end{array}$ & $\begin{array}{l}-0.881 \\
(0.619)\end{array}$ \\
\hline Duration 9+ & $\begin{array}{l}-1.116 \\
(0.758)\end{array}$ & & $\begin{array}{c}0.722 \\
(0.518)\end{array}$ & $\begin{array}{l}0.297 \\
(0.355)\end{array}$ & $\begin{array}{l}-0.243 \\
(0.320)\end{array}$ & $\begin{array}{c}1.003^{* * *} \\
(0.262)\end{array}$ & $\begin{array}{c}0.665^{* * *} \\
(0.208)\end{array}$ & $\begin{array}{l}0.690^{* *} \\
(0.279)\end{array}$ & $\begin{array}{c}0.077 \\
(0.259)\end{array}$ & $\begin{array}{c}0.854^{* * * *} \\
(0.204)\end{array}$ & $\begin{array}{c}0.265 \\
(0.297)\end{array}$ & $\begin{array}{c}0.688^{* * * *} \\
(0.140)\end{array}$ & $\begin{array}{l}0.563^{*} \\
(0.325)\end{array}$ & $\begin{array}{c}0.082 \\
(0.446)\end{array}$ \\
\hline Constant & $\begin{array}{c}-6.577^{* * *} \\
(1.299)\end{array}$ & $\begin{array}{c}-3.228^{* *} \\
(1.362)\end{array}$ & $\begin{array}{c}-6.080 * * * \\
(1.140)\end{array}$ & $\begin{array}{c}-1.862^{* * *} \\
(0.781)\end{array}$ & $\begin{array}{c}-3.770^{* * *} \\
(0.792)\end{array}$ & $\begin{array}{c}-5.063^{* * *} \\
(0.485)\end{array}$ & $\begin{array}{c}-5.023^{* * * *} \\
(0.744)\end{array}$ & $\begin{array}{c}-2.958^{* * *} \\
(0.831)\end{array}$ & $\begin{array}{c}-4.922 * * * \\
(0.812)\end{array}$ & $\begin{array}{c}-2.887 * * * \\
(0.604)\end{array}$ & $\begin{array}{c}-6.890 * * * \\
(1.383)\end{array}$ & $\begin{array}{c}-3.764 * * * \\
(0.521)\end{array}$ & $\begin{array}{c}-6.686^{* * *} \\
(1.110)\end{array}$ & $\begin{array}{c}-5.413^{* * * *} \\
(1.074)\end{array}$ \\
\hline $\begin{array}{l}\text { Log-Likel. } \\
\text { N (Households) }\end{array}$ & & & $\begin{array}{r}-44 \\
13\end{array}$ & & $\begin{array}{r}-72 \\
1\end{array}$ & $\begin{array}{l}7.37 \\
31\end{array}$ & & & & $\begin{array}{l}4.94 \\
73\end{array}$ & $\begin{array}{r}-12 \\
2\end{array}$ & 4.35 & & \\
\hline
\end{tabular}

(Continues) 


\begin{tabular}{|c|c|c|c|c|c|c|c|c|c|c|c|c|}
\hline \multirow[b]{3}{*}{ Outstanding Loan } & \multicolumn{2}{|c|}{ Ireland } & \multicolumn{2}{|c|}{ Italy } & \multicolumn{2}{|c|}{ Netherlands } & \multicolumn{2}{|c|}{ Portugal } & \multicolumn{2}{|c|}{ Spain } & \multicolumn{2}{|c|}{ UK } \\
\hline & Own & Rent & Own & Rent & Own & Rent & Own & Rent & Own & Rent & Own & Rent \\
\hline & $\begin{array}{c}0.497 \\
(0.573)\end{array}$ & $\begin{array}{c}0.265 \\
(0.688)\end{array}$ & $\begin{array}{l}-0.266 \\
(0.390)\end{array}$ & $\begin{array}{c}0.435 \\
(0.572)\end{array}$ & $\begin{array}{c}-0.819 * * \\
(0.347)\end{array}$ & $\begin{array}{c}0.131 \\
(0.372)\end{array}$ & $\begin{array}{l}-0.559 \\
(0.552)\end{array}$ & $\begin{array}{l}-0.625 \\
(1.106)\end{array}$ & $\begin{array}{c}-1.238^{* * *} \\
(0.453)\end{array}$ & $\begin{array}{l}-0.872 \\
(0.744)\end{array}$ & $\begin{array}{c}-0.582^{* *} \\
(0.228)\end{array}$ & $\begin{array}{c}0.363 \\
(0.370)\end{array}$ \\
\hline Retired & $\begin{array}{l}-0.049 \\
(0.611)\end{array}$ & $\begin{array}{l}-0.288 \\
(0.772)\end{array}$ & $\begin{array}{l}-0.368 \\
(0.258)\end{array}$ & $\begin{array}{l}-0.581 \\
(0.354)\end{array}$ & $\begin{array}{l}-0.537 \\
(0.592)\end{array}$ & $\begin{array}{c}-1.619 * * * \\
(0.461)\end{array}$ & $\begin{array}{c}0.091 \\
(0.243)\end{array}$ & $\begin{array}{l}-0.433 \\
(0.321)\end{array}$ & $\begin{array}{c}-0.545^{* * *} \\
(0.209)\end{array}$ & $\begin{array}{l}-0.430 \\
(0.368)\end{array}$ & $\begin{array}{l}-0.057 \\
(0.194)\end{array}$ & $\begin{array}{l}-0.246 \\
(0.285)\end{array}$ \\
\hline Spouse Retired & $\begin{array}{l}-0.538 \\
(1.049)\end{array}$ & $\begin{array}{c}0.199 \\
(0.940)\end{array}$ & $\begin{array}{l}-0.494 \\
(0.368)\end{array}$ & $\begin{array}{l}-0.070 \\
(0.441)\end{array}$ & $\begin{array}{l}-0.386 \\
(1.019)\end{array}$ & $\begin{array}{l}-1.127^{*} \\
(0.636)\end{array}$ & $\begin{array}{l}-0.113 \\
(0.286)\end{array}$ & $\begin{array}{c}0.219 \\
(0.366)\end{array}$ & $\begin{array}{c}0.044 \\
(0.240)\end{array}$ & $\begin{array}{l}-1.055 \\
(0.725)\end{array}$ & $\begin{array}{l}-0.314 \\
(0.232)\end{array}$ & $\begin{array}{c}-1.382^{* * *} \\
(0.521)\end{array}$ \\
\hline Loss of Spouse & & & $\begin{array}{l}-1.634 \\
(1.070)\end{array}$ & $\begin{array}{l}-0.426 \\
(0.626)\end{array}$ & $\begin{array}{c}0.343 \\
(0.447)\end{array}$ & $\begin{array}{l}-0.462 \\
(0.349)\end{array}$ & $\begin{array}{l}-1.033^{*} \\
(0.625)\end{array}$ & $\begin{array}{c}0.110 \\
(0.543)\end{array}$ & $\begin{array}{l}-0.409 \\
(0.370)\end{array}$ & $\begin{array}{c}0.865 \\
(0.567)\end{array}$ & $\begin{array}{c}-0.880^{* *} \\
(0.426)\end{array}$ & $\begin{array}{c}-1.231^{* *} \\
(0.489)\end{array}$ \\
\hline Couple & $\begin{array}{c}2.233 \\
(1.376)\end{array}$ & $\begin{array}{l}-0.722 \\
(0.639)\end{array}$ & $\begin{array}{l}0.595^{*} \\
(0.339)\end{array}$ & $\begin{array}{l}-0.483 \\
(0.368)\end{array}$ & $\begin{array}{l}1.126^{* *} \\
(0.493)\end{array}$ & $\begin{array}{c}0.720 * * * \\
(0.200)\end{array}$ & $\begin{array}{c}1.375^{* * *} \\
(0.430)\end{array}$ & $\begin{array}{l}-0.157 \\
(0.346)\end{array}$ & $\begin{array}{c}1.189 * * * \\
(0.309)\end{array}$ & $\begin{array}{c}0.510 \\
(0.432)\end{array}$ & $\begin{array}{c}1.111^{* * *} \\
(0.283)\end{array}$ & $\begin{array}{c}0.976^{* * *} \\
(0.273)\end{array}$ \\
\hline Presence of Children & $\begin{array}{c}0.118 \\
(0.666)\end{array}$ & $\begin{array}{l}-1.373 \\
(1.145)\end{array}$ & $\begin{array}{l}-0.513 \\
(0.385)\end{array}$ & $\begin{array}{c}0.225 \\
(0.400)\end{array}$ & $\begin{array}{l}-0.324 \\
(0.470)\end{array}$ & $\begin{array}{l}-0.755 \\
(0.622)\end{array}$ & $\begin{array}{l}-0.382 \\
(0.331)\end{array}$ & $\begin{array}{c}0.534 \\
(0.372)\end{array}$ & $\begin{array}{c}-0.773^{* *} \\
(0.300)\end{array}$ & $\begin{array}{c}0.122 \\
(0.405)\end{array}$ & $\begin{array}{l}-0.094 \\
(0.326)\end{array}$ & $\begin{array}{l}-0.285 \\
(0.664)\end{array}$ \\
\hline Health Shock & $\begin{array}{c}0.162 \\
(0.601)\end{array}$ & $\begin{array}{l}-0.480 \\
(0.760)\end{array}$ & $\begin{array}{l}0.433^{*} \\
(0.250)\end{array}$ & $\begin{array}{c}0.146 \\
(0.299)\end{array}$ & $\begin{array}{l}-0.037 \\
(0.369)\end{array}$ & $\begin{array}{c}0.268 \\
(0.177)\end{array}$ & $\begin{array}{c}0.342 \\
(0.267)\end{array}$ & $\begin{array}{c}0.780 * * * \\
(0.270)\end{array}$ & $\begin{array}{c}-0.555^{* *} \\
(0.229)\end{array}$ & $\begin{array}{l}-0.072 \\
(0.332)\end{array}$ & $\begin{array}{c}0.613^{* * *} \\
(0.184)\end{array}$ & $\begin{array}{l}-0.220 \\
(0.277)\end{array}$ \\
\hline Health Shock-Spouse & $\begin{array}{l}-0.077 \\
(0.563)\end{array}$ & $\begin{array}{c}0.401 \\
(0.857)\end{array}$ & $\begin{array}{l}-0.219 \\
(0.339)\end{array}$ & $\begin{array}{l}-0.133 \\
(0.456)\end{array}$ & $\begin{array}{l}-0.244 \\
(0.426)\end{array}$ & $\begin{array}{c}0.188 \\
(0.235)\end{array}$ & $\begin{array}{c}0.299 \\
(0.294)\end{array}$ & $\begin{array}{c}0.091 \\
(0.411)\end{array}$ & $\begin{array}{l}-0.077 \\
(0.227)\end{array}$ & $\begin{array}{l}-0.081 \\
(0.383)\end{array}$ & $\begin{array}{c}0.030 \\
(0.273)\end{array}$ & $\begin{array}{c}-0.454 \\
(0.529)\end{array}$ \\
\hline Living in Appartment & $\begin{array}{l}2.059^{*} \\
(1.110)\end{array}$ & $\begin{array}{l}-0.496 \\
(1.258)\end{array}$ & $\begin{array}{c}0.059 \\
(0.257)\end{array}$ & $\begin{array}{c}0.094 \\
(0.314)\end{array}$ & $\begin{array}{l}-0.671 \\
(0.523)\end{array}$ & $\begin{array}{c}-0.397 * * \\
(0.187)\end{array}$ & $\begin{array}{l}0.603^{*} \\
(0.310)\end{array}$ & $\begin{array}{l}-0.260 \\
(0.354)\end{array}$ & $\begin{array}{c}0.285 \\
(0.182)\end{array}$ & $\begin{array}{l}-0.068 \\
(0.311)\end{array}$ & $\begin{array}{c}0.027 \\
(0.374)\end{array}$ & $\begin{array}{l}-0.158 \\
(0.283)\end{array}$ \\
\hline Housing Costs a Burden & $\begin{array}{c}0.555 \\
(0.654)\end{array}$ & $\begin{array}{l}1.350^{* *} \\
(0.655)\end{array}$ & $\begin{array}{c}0.870^{* * *} \\
(0.355)\end{array}$ & $\begin{array}{c}0.773 * * \\
(0.361)\end{array}$ & $\begin{array}{c}1.026 * * * \\
(0.369)\end{array}$ & $\begin{array}{c}1.196 * * * \\
(0.166)\end{array}$ & $\begin{array}{c}0.823 * * * \\
(0.231)\end{array}$ & $\begin{array}{c}0.410 \\
(0.263)\end{array}$ & $\begin{array}{c}1.573 * * * \\
(0.219)\end{array}$ & $\begin{array}{c}1.284^{* * *} \\
(0.364)\end{array}$ & $\begin{array}{c}1.835 * * * \\
(0.695)\end{array}$ & $\begin{array}{c}1.847 * * * \\
(0.517)\end{array}$ \\
\hline HH Income & $\begin{array}{l}-0.166 \\
(0.132)\end{array}$ & $\begin{array}{c}-0.737 * * * \\
(0.239)\end{array}$ & $\begin{array}{l}-0.158^{*} \\
(0.094)\end{array}$ & $\begin{array}{l}-0.119 \\
(0.141)\end{array}$ & $\begin{array}{l}-0.062 \\
(0.098)\end{array}$ & $\begin{array}{c}-0.350^{* * *} \\
(0.110)\end{array}$ & $\begin{array}{l}-0.144 \\
(0.153)\end{array}$ & $\begin{array}{l}-0.233 \\
(0.225)\end{array}$ & $\begin{array}{c}-0.181^{* *} \\
(0.089)\end{array}$ & $\begin{array}{c}0.004 \\
(0.094)\end{array}$ & $\begin{array}{l}-0.198^{*} \\
(0.101)\end{array}$ & $\begin{array}{c}-0.655^{* * *} \\
(0.158)\end{array}$ \\
\hline HH Wealth & $\begin{array}{l}0.516^{* *} \\
(0.253)\end{array}$ & $\begin{array}{c}0.579 \\
(0.716)\end{array}$ & $\begin{array}{c}0.603 * * * \\
(0.142)\end{array}$ & $\begin{array}{l}-0.863 \\
(0.979)\end{array}$ & $\begin{array}{l}-0.079 \\
(0.231)\end{array}$ & $\begin{array}{l}-0.831 \\
(0.742)\end{array}$ & $\begin{array}{c}0.937 * * * \\
(0.251)\end{array}$ & $\begin{array}{c}0.162 \\
(0.920)\end{array}$ & $\begin{array}{c}0.341^{* * *} \\
(0.132)\end{array}$ & $\begin{array}{l}0.269^{*} \\
(0.154)\end{array}$ & $\begin{array}{c}0.210 \\
(0.188)\end{array}$ & $\begin{array}{l}-0.273 \\
(0.468)\end{array}$ \\
\hline Cohort Effect & $\begin{array}{c}0.007 \\
(0.033)\end{array}$ & $\begin{array}{c}0.069 \\
(0.058)\end{array}$ & $\begin{array}{l}-0.027 \\
(0.024)\end{array}$ & $\begin{array}{l}-0.030^{*} \\
(0.018)\end{array}$ & $\begin{array}{l}-0.035 \\
(0.027)\end{array}$ & $\begin{array}{c}-0.059 * * * \\
(0.012)\end{array}$ & $\begin{array}{c}0.005 \\
(0.021)\end{array}$ & $\begin{array}{l}-0.007 \\
(0.021)\end{array}$ & $\begin{array}{l}-0.023 \\
(0.015)\end{array}$ & $\begin{array}{c}-0.070 * * \\
(0.030)\end{array}$ & $\begin{array}{c}-0.045^{* * *} \\
(0.015)\end{array}$ & $\begin{array}{c}-0.089 * * * \\
(0.019)\end{array}$ \\
\hline Duration 3-6 & $\begin{array}{l}-0.517 \\
(0.696)\end{array}$ & $\begin{array}{c}0.185 \\
(0.651)\end{array}$ & $\begin{array}{c}0.303 \\
(0.242)\end{array}$ & $\begin{array}{c}0.272 \\
(0.281)\end{array}$ & $\begin{array}{l}-0.550^{*} \\
(0.327)\end{array}$ & $\begin{array}{c}0.233 \\
(0.177)\end{array}$ & $\begin{array}{c}0.354 \\
(0.249)\end{array}$ & $\begin{array}{c}0.230 \\
(0.275)\end{array}$ & $\begin{array}{c}0.123 \\
(0.184)\end{array}$ & $\begin{array}{l}-0.094 \\
(0.318)\end{array}$ & $\begin{array}{c}-0.782^{* * *} \\
(0.250)\end{array}$ & $\begin{array}{l}-0.557^{*} \\
(0.293)\end{array}$ \\
\hline Duration 6-9 & $\begin{array}{c}0.325 \\
(0.688)\end{array}$ & $\begin{array}{c}0.124 \\
(0.748)\end{array}$ & $\begin{array}{c}0.011 \\
(0.332)\end{array}$ & $\begin{array}{c}0.293 \\
(0.348)\end{array}$ & $\begin{array}{l}-0.479 \\
(0.393)\end{array}$ & $\begin{array}{l}-0.539 * \\
(0.278)\end{array}$ & $\begin{array}{l}-0.220 \\
(0.379)\end{array}$ & $\begin{array}{l}-0.092 \\
(0.415)\end{array}$ & $\begin{array}{l}-0.243 \\
(0.269)\end{array}$ & $\begin{array}{l}-0.483 \\
(0.490)\end{array}$ & $\begin{array}{l}-0.104 \\
(0.241)\end{array}$ & $\begin{array}{l}-0.537 \\
(0.348)\end{array}$ \\
\hline Duration 9+ & $\begin{array}{l}1.250^{* *} \\
(0.579)\end{array}$ & $\begin{array}{l}1.081^{*} \\
(0.594)\end{array}$ & $\begin{array}{l}-0.139 \\
(0.349)\end{array}$ & $\begin{array}{l}0.605^{*} \\
(0.315)\end{array}$ & $\begin{array}{l}-0.138 \\
(0.326)\end{array}$ & $\begin{array}{c}0.204 \\
(0.198)\end{array}$ & $\begin{array}{l}0.651^{* *} \\
(0.292)\end{array}$ & $\begin{array}{c}0.182 \\
(0.408)\end{array}$ & $\begin{array}{l}-0.055 \\
(0.238)\end{array}$ & $\begin{array}{l}-0.143 \\
(0.390)\end{array}$ & $\begin{array}{l}0.389 * * \\
(0.192)\end{array}$ & $\begin{array}{c}0.663^{* * *} \\
(0.223)\end{array}$ \\
\hline Constant & $\begin{array}{c}-9.075^{* * *} \\
(2.440)\end{array}$ & $\begin{array}{c}-6.050 * * * \\
(1.929)\end{array}$ & $\begin{array}{c}-5.155^{* * *} \\
(1.064)\end{array}$ & $\begin{array}{c}-3.868^{* * *} \\
(0.962)\end{array}$ & $\begin{array}{c}-4.972 * * * \\
(0.985)\end{array}$ & $\begin{array}{c}-2.344 * * * \\
(0.465)\end{array}$ & $\begin{array}{c}-6.672 * * * \\
(0.895)\end{array}$ & $\begin{array}{c}-4.145^{* * *} \\
(0.931)\end{array}$ & $\begin{array}{c}-5.119 * * * \\
(0.718)\end{array}$ & $\begin{array}{c}-3.218 * * * \\
(1.165)\end{array}$ & $\begin{array}{c}-4.892^{* * *} \\
(1.043)\end{array}$ & $\begin{array}{c}0.435 \\
(0.823)\end{array}$ \\
\hline $\begin{array}{l}\text { Log-Likel. } \\
\text { N (Households) }\end{array}$ & \multicolumn{2}{|c|}{$\begin{array}{c}-177.28 \\
1542\end{array}$} & \multicolumn{2}{|c|}{-752.57} & \multicolumn{2}{|r|}{30} & \multicolumn{2}{|c|}{-678.65} & \multicolumn{2}{|c|}{-894.93} & -883.10 & \\
\hline
\end{tabular}

See notes in Table 6. 